\title{
Key factors controlling shale oil enrichment in saline lacustrine rift basin: implications from two shale oil wells in Dongpu Depression, Bohai Bay Basin
}

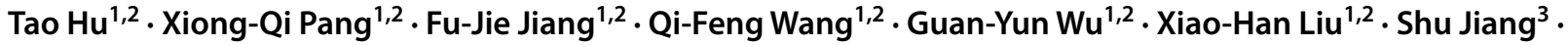 \\ Chang-Rong $\mathrm{Li}^{1,2} \cdot$ Tian-Wu Xu${ }^{4} \cdot$ Yuan-Yuan Chen ${ }^{1,2}$
}

Received: 7 April 2020 / Accepted: 2 November 2020 / Published online: 20 May 2021

(c) The Author(s) 2021

\begin{abstract}
Comparative analyses of petroleum generation potential, reservoir volume, frackability, and oil mobility were conducted on 102 shale cores from the Dongpu Depression. Results show the shale has high organic matter contents composed of oil-prone type I and type II kerogens within the oil window. Various types of pores and fractures exist in the shale, with a porosity of up to $14.9 \%$. The shale has high brittle mineral contents, extensive fractures, and high potential for oil mobility due to high seepage capacity and overpressure. Although the petroleum generation potential of the shale at Well PS18-8 is relatively greater than that at Well PS18-1, oil content of the latter is greater due to the greater TOC. The porosity and fracture density observed in Well PS18-1 are greater and more conducive to shale oil enrichment. Although the shales in Wells PS18-1 and PS18-8 have similar brittle mineral contents, the former is more favorable for anthropogenic fracturing due to a higher preexisting fracture density. Besides, the shale at Well PS18-1 has a higher seepage capacity and overpressure and therefore a higher oil mobility. The fracture density and overpressure play key roles in shale oil enrichment.
\end{abstract}

Keywords Petroleum generation potential $\cdot$ Reservoir volume $\cdot$ Frackability $\cdot$ Oil mobility $\cdot$ Shale oil enrichment $\cdot$ Dongpu Depression · Saline lacustrine rift basin

\section{Introduction}

Shale oil refers to the oil generated in organic-rich shales and stored in them or adjacent organic-lean intervals (Jarvie

Edited by Jie Hao and Chun-Yan Tang

$\mathrm{Tao} \mathrm{Hu}$

thu@cup.edu.cn

Xiong-Qi Pang

pangxq@cup.edu.cn

Fu-Jie Jiang

jiangfj@cup.edu.cn

1 State Key Laboratory of Petroleum Resources and Prospecting, China University of Petroleum, Beijing 102249, China

2 College of Geosciences, China University of Petroleum, Beijing 102249, China

3 Energy \& Geoscience Institute, University of Utah, Salt Lake City, UT 84108, USA

4 Research Institute of Exploration and Development, Zhongyuan Oilfield Company, SINOPEC, Puyang, Henan 457001, China
2012). Shale oil has been found in the USA, such as Barnett and Antelope tight shale oil, Bakken and Monterey fractured shale oil, and Bakken and Eagle Ford hybrid shale oil systems (Jarvie 2012). The USA's successful marine shale oil revolution has boosted confidence in recreating success in lacustrine basins. Numerous lacustrine basins are distributed across the world, such as the USA (Katz 1995), Brazil (Mello et al. 1991), India (Saikia and Dutta 1980), Indonesia (Katz and Kahle 1988), and China (Wang et al. 2019), containing numerous shale oil resources. China is rich in lacustrine shale oil resources with a recoverable amount of $43.5 \times 10^{8} \mathrm{t}$, ranking the third in the world (EIA 2008). which were found in the Dongying Depression (Wang et al. 2015a), Dongpu Depression (DD) (Wang et al. 2014, 2015a), Cangdong Sag (Zhao et al. 2019), and Zhanhua Depression (Li et al. 2017) in Bohai Bay Basin, the Bohai Sea area (Jiang et al. 2016), and the Qingshankou Formation in Songliao 
Basin (Liu et al. 2017). In particular, for the Kongdian Formation in Cangdong Sag, the natural daily yields of two horizontal shale oil wells GD-1701H and GD1702H achieved 20-30 $\mathrm{m}^{3}$ for more than 300 days by now. Besides, the well G1608 obtained a peak daily oil yield of $60 \mathrm{~m}^{3}$ after fracturing, producing for 105 days and reaching a cumulative oil production of more than $1704 \mathrm{~m}^{3}$ (Zhao et al. 2019). These discoveries suggest promising shale oil exploration prospects in lacustrine shale oil (Li et al. 2014; Wang et al. 2019).

Significant differences exist between marine and lacustrine shale oil plays. Marine shales are widely distributed and have high organic matter contents, high thermal maturity, high brittle mineral contents, and high formation pressure. They contain good-quality organic matter dominated by type II kerogen and generate light oils with low wax content and viscosity (Enderlin et al. 2011; Ferrill et al. 2014; Jarvie et al. 2007; Nie et al. 2016; Wang et al. 2014). By contrast, lacustrine shales are distributed over a small area and exhibit a strong heterogeneity. The organic matter in the shales shows large variations in contents and compositions dominated by type I and type II kerogens, which have low thermal maturity, low quartz mineral content and mainly generate waxy oil (Katz and Lin 2014; Chen et al. 2015; Wang et al. 2014, 2015a, b, 2019; Nie et al. 2016). Clearly, lacustrine basins and marine basins have distinct differences in geological and geochemical characteristics (Jiang et al. 2017; Wang et al. 2019). It is difficult to arbitrarily apply the shale oil enrichment laws of productive shale oil plays in the USA to China.

Recently, attempts have been made to investigate the shale oil enrichment in lacustrine basins and identify factors for the enrichment. Liu et al. (2013) investigated the shale oil enrichment laws for Lucaogou Formation, Malang Depression, Santanghu Basin, and hold that the fractures would promote the oil and gas loss in the shale system and result in the decreasing oil and gas enrichment. This is consistent with the studies conducted by Rodriguez and Paul (2010). Li et al. (2014) studied shale oil system in Hetaoyuan Formation of Biyang Depression, Nanxiang Basin, and found that oil enrichment was controlled by the oil generation capacity, reservoir volume, and preservation conditions and the producibility was controlled by the shale frackability, oil density, and development scheme. Finally, Li et al. (2014) concluded thermal maturity is the key factor controlling shale oil enrichment, and the southeastern regions with deep burial depth are favorable for shale oil enrichment, which is consistent with the studies conducted by Nie et al. (2016) and Wang et al. (2017). Bai et al. (2017) hold that the oil generation capacity and evolution, reservoir volume, and overpressure control the oil enrichment, the oil density, viscosity, and gas-oil ratio control the oil movability, the lithological combination and brittle mineral contents of shale control the frackability. Liu et al. (2018) studied the petrological characteristics and shale oil enrichment in Qingshankou Formation of Gulong Sag, Songliao Basin,
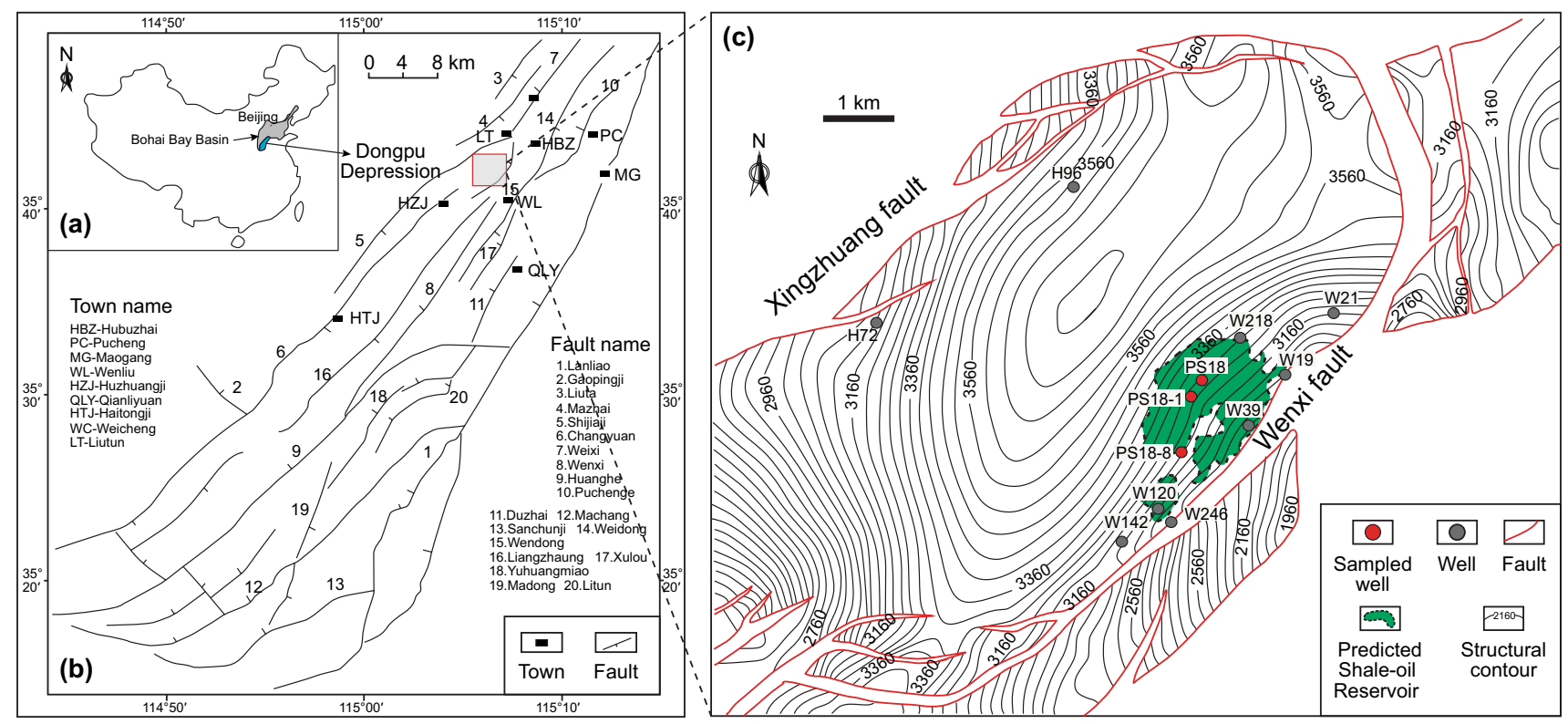

Fig. 1 Geological map of Liutun Sag, Dongpu Depression (DD). a Overview map of China showing the location of the Bohai Bay Basin and DD, b regional structural map of the DD showing the location of the Liutun Sag (modified after Wang et al., 2015a), and c structure contour map of the $\mathrm{Es}_{3}{ }^{\mathrm{U}}$ (an upper sub-member of third member of the Paleogene Shahejie Formation) and key wells in the Liutun Sag 
and concluded that the laminated siliceous mudstone with moderate TOC is most favorable for shale oil enrichment. Lots of saline lacustrine rift basins develop in China and are rich in shale oil resources. Although many studies have been conducted on the factors controlling shale oil enrichment, few systematic analyses about the macrogeological conditions have been made, which are significant in "sweet spots" prediction in shale oil system.

The DD is a typical saline lacustrine rift basin in China, in which the third member of the Paleogene Shahejie Formation $\left(\mathrm{Es}_{3}\right)$ is thick and rich in shale oil resources (Wang et al. 2014, 2015a, 2019). Since 1976, oil shows had been discovered from the $\mathrm{Es}_{3}$ shale of Wells Wen 6, Wen 300, and Wen 201 in the DD and even yielded some oil (Mu et al 2003; Leng et al. 2006). In 2010, the Well PS18-1 obtained a daily oil yield of $430 \mathrm{~m}^{3}$ with a $5 \mathrm{~mm}$ size nozzle in the depth of 3,255-3,258 $\mathrm{m}$ in the $\mathrm{Es}_{3}{ }^{\mathrm{U}}$ shale (Zhang et al 2015), which is the highest single-well production obtained in a shale oil exploration well recently (Zhang et al. 2012; Wang et al. 2014). However, only oil shows were observed in subsequent drilling Well PS18-8, which was located only approximately $800 \mathrm{~m}$ to the south of Well PS18-1. Under similar structural conditions, why do these two wells exhibit such a remarkable difference in shale oil yield? Obviously, the two wells are excellent objects for conducting shale oil enrichment studies. However, in the DD, the subsequent studies mainly investigated the generally geological and geochemical characteristics of the $\mathrm{Es}_{3}$ shale (Deng et al. 2015; Wang et al. 2014, 2015a; Zhang et al. 2015), rarely focused on the shale oil enrichment laws.

Targeting the $\mathrm{Es}_{3}{ }^{\mathrm{U}}$ shales in the Wells PS18-1 and PS188 , this study utilized continuous cores to reveal key factors controlling shale oil enrichment. Detailed geological and geochemical studies were carried out to examine petroleum generation potential, reservoir capacity, frackability, and oil mobility. Comparative analyses were conducted regarding their differences in production capacity. Finally, the key factors controlling shale oil enrichment were proposed. The results obtained in this study can provide significant references for further shale oil exploration in saline lacustrine rift basins across the world.

\section{Geological background}

The DD, located in the southwestern corner of the Bohai Bay Basin, is a Mesozoic and Cenozoic lacustrine rift basin in Paleozoic craton with an area of $5300 \mathrm{~km}^{2}$ (Fig. 1) (Chen et al. 2000). The DD extends to the NNE-SSW and is narrow in the south but broad in the north (Chen et al. 2013). Four tectonic movements and six tectonic evolution stages occurred (Chen et al. 2013), forming a set of super-thick continental strata dominated by Paleogene and
Neogene strata. Located in the central western region of the DD (Fig. 1), the Liutun Sag is the second-largest petroleum generating sag. The strata consist of the Paleogene Kongdian, Shahejie and Dongying Formations, Neogene Minghuazhen and Guantao Formations, and the Quaternary Pingyuan Formation. The strata have a thickness of approximately $6000 \mathrm{~m}$, with $\mathrm{Es}_{3}$ as the main source rock and reservoir (Wang et al. 2015a). The $\mathrm{Es}_{3}$ shale is divided into $\mathrm{Es}_{3}{ }^{\mathrm{U}}, \mathrm{Es}_{3}{ }^{\mathrm{M}}$, and $\mathrm{Es}_{3}{ }^{\mathrm{L}}$ (middle and lower submember of the $\mathrm{Es}_{3}$ ), from top to bottom. The shale oil play was developed in $\mathrm{Es}_{3}{ }^{\mathrm{U}}$ at a burial depth of $3200-4000 \mathrm{~m}$, consisting of clastic mudstones, carbonate rocks, and evaporites (Fig. 2). Faults are not developed in the central Liutun Sag. However, due to the impact of the marginal faults at the eastern and western sides of the sag, numerous small secondary faults occur near these faults and are favorable for fracture development (Wang et al. 2004, 2015a).

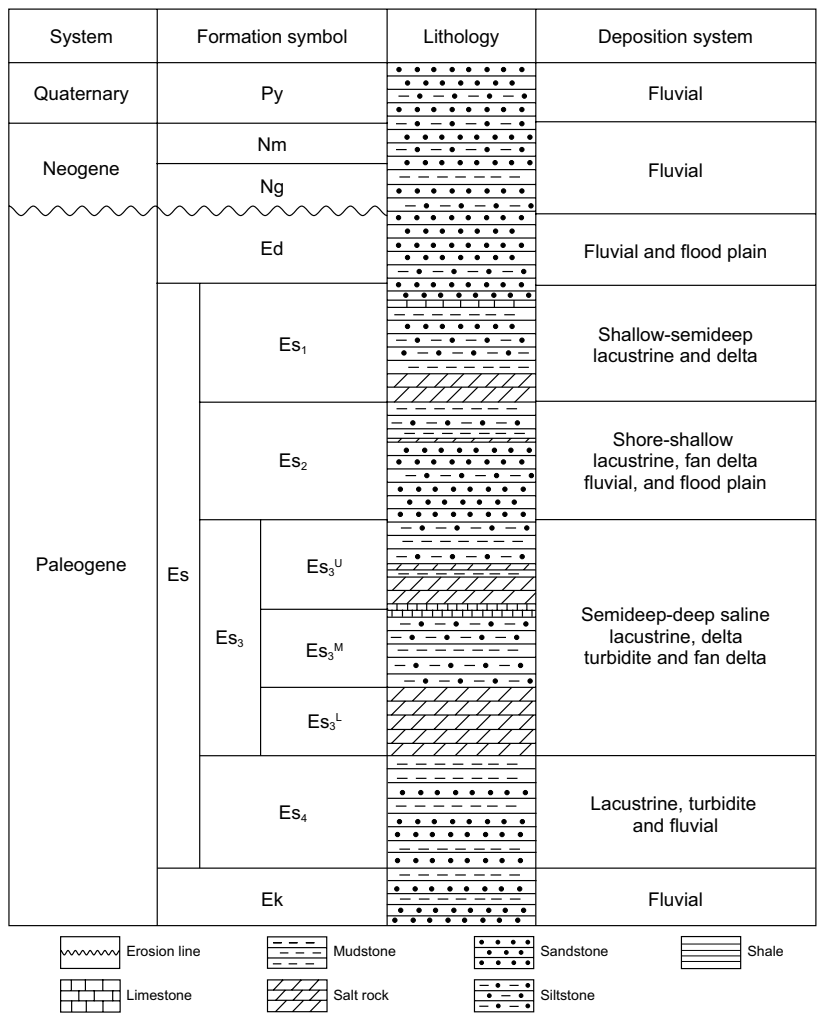

Fig. 2 Generalized stratigraphy and depositional system of the Liutun Sag, DD (modified after Wang et al., 2015a; Luo et al., 2016). Es: Shahejie Formation; Ed: Dongying Formation; Ng: Guantao Formation; Nm: Minghuazhen Formation; Qp: Pingyuan Formation; Es ${ }_{3}$ : Third member of Paleogene Shahejie Formation; $\mathrm{Es}_{3}{ }^{\mathrm{L}}$ : Lower submember of $\mathrm{Es}_{3} ; \mathrm{Es}_{3}{ }^{\mathrm{M}}$ : Middle sub-member of the $\mathrm{Es}_{3}$; $\mathrm{Es}_{3}{ }^{\mathrm{U}}$ : Upper sub-member of $\mathrm{Es}_{3} ; \mathrm{Es}_{4}$ : Forth member of Paleogene Shahejie Formation; Ek: Paleogene Kongdian Formation 

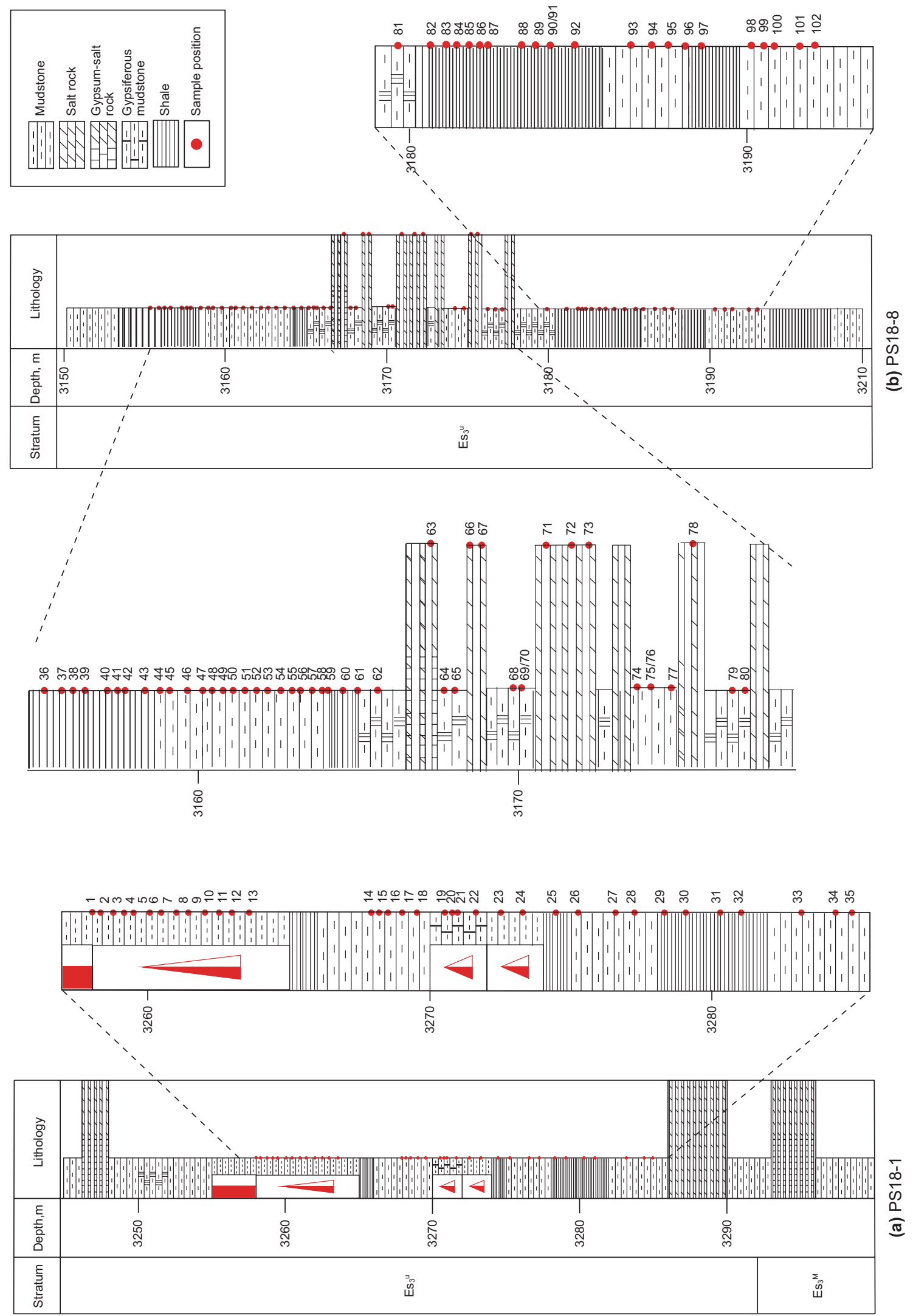

Fig. 3 Lithological column of main intervals of interest in Wells PS18-1 and PS18-8 of the Liutun Sag, DD, showing the locations of the core samples 


\section{Samples and methods}

\subsection{Samples}

One hundred two shale samples were cored from Wells PS18-1 (3258-3285 m) and PS18-8 (3155-3193 m) in the $\mathrm{Es}_{3}{ }^{\mathrm{U}}$ shale oil play (Fig. 3).

\subsection{Methods}

For TOC analysis, 100 milligrams of shale samples was washed and ground to 100 mesh powder and immersed in dilute hydrochloric acid to remove inorganic carbon. Then, the samples were rinsed repeatedly with distilled water until a neutral $\mathrm{pH}$ was achieved and were subsequently dried in an oven at $60-80{ }^{\circ} \mathrm{C}$. The samples were then analyzed using a LECO CS-400 instrument (Espitalié et al. 1977). Soxhlet extraction was performed on the shale samples with chloroform for $72 \mathrm{~h}$. To obtain rock extract "A," the fractions of saturated hydrocarbons, aromatic hydrocarbons, nonhydrocarbons, and asphaltenes were tested by reference to the Oil and Gas Industry Standard of the People's Republic of China (Zheng et al. 2008).

Mineral composition was obtained by X-ray diffraction (XRD) analysis with a Panalytical X'Pert PRO diffractometer at a temperature of $24{ }^{\circ} \mathrm{C}$ and humidity of $35 \%$ with a $2 \%$ min $2 \theta$ rotation speed and a $\mathrm{Cu} \mathrm{Ka}$ emission source powered at $40 \mathrm{kV}$ and $30 \mathrm{~mA}$. This study adopted the Rietveld method for quantitative phase analysis (Ufer et al. 2008).

The biological microscope with fluorescence emission was utilized to observe size, morphology, and fluorescence of the organic matter in the shale samples to identify the kerogen macerals. Thin slices of the shale samples were prepared using glycerol and examined with $40 \times$ object lens to determine the representative size of the macerals, which was regarded as the standard statistical unit. After that, the visual field was moved at equal distance interval relative to the initial position. In each visual field, the marcels were identified and counted. The visual field and the marcels observed in that field were labeled by the coordination of the field center to the initial position.

Kerogen type index (TI) was calculated by utilizing the method proposed by Cao (1985), which has been used to evaluate kerogen types of lacustrine shale (Tao et al. 2012; Luo et al. 2017). The maceral of kerogen is composed of sapropelinite, exinite, vitrinite, and inertinite. Generally, the sapropelinite mainly originates from the lower plankton, and the higher the content of sapropelinite is, the more favorable the kerogen is for petroleum generation. Inertinite is formed from xylems of higher plants by intense carbonization or carbonization after gelation, with high carbon content and low hydrogen content. Therefore, the sapropelinite and inertinite have the greatest and the lowest petroleum generation potential, respectively, and therefore the weighting coefficient are +100 and -100 . Exinite is mainly originated from chitin tissues of terrestrial or aquatic higher plants. Esters with higher fatty acids and higher alcohols in the chitin tissues can be reduced by hydrolysis to generate petroleum. Therefore, the exinite has certain petroleum generation potential, and the weighting coefficient is +50 . Vitrinite is mainly formed from xylems of higher plants. During bituminization, the asphaltenes formed by deoxidization of long-chain acids, alcohols, and esters are mainly absorbed by vitrinite. The petroleum generation potential of the vitrinite is greater than inertinite, but significantly lower than sapropelinite and exinite. Following the weighting coefficient proposed by the EXXON, the weighting coefficient of the vitrinite is -75 (Cao 1985). The calculation function of the $T I$ is as follows:

$T I=(a \times 100+b \times 50-c \times 75-d \times 100) / 100$

where $a, b, c, d$ are the contents of the sapropelinite, exinite, vitrinite, and inertinite, respectively. The kerogen with $T I>80 \%$ is type I, that with $0<T I<80 \%$ is type II, and that with $T I<0$ is type III.

High-resolution field emission-scanning electron microscopy (FE-SEM) was utilized to study the fractures and pores. The experimental instrument was a FEI Quanta 200F scanning electron microscope set to a voltage of $20 \mathrm{kV}$ and an object distance of 10-12 mm. A QUANTAX400 energy spectrometer was used in energy spectrum analyses at an acceleration voltage of $20 \mathrm{kV}$ with a dead time of 35-40 $\%$, and a live time of $100 \mathrm{~s}$. The experiment was conducted at the temperature of $20{ }^{\circ} \mathrm{C}$ and humidity of $50 \%$. To analyze pores with sizes smaller than one micrometer, the samples were first subjected to argon ion polishing (Gatan 691. CS) followed by gold plating (SCD500) prior to taking the measurements. The measurements were conducted on the natural section samples directly for observation of fractures and pores with sizes greater than several micrometers (Jiao et al. 2016).

\section{Results and discussion}

\subsection{Petroleum generation potential and shale oil content}

\subsubsection{Organic matter content}

The TOC values of the shale samples range between $0.35 \%$ and $5.7 \%$ with a mean of $1.83 \%$ (Table 1), showing that 74 $\%$ of the shale is good to excellent source rocks (Fig. 4). The $\mathrm{Es}_{3}{ }^{\mathrm{U}}$ shale is distributed throughout the entire DD, with the greatest thickness (up to $325 \mathrm{~m}$ ) in the center. The thickness 


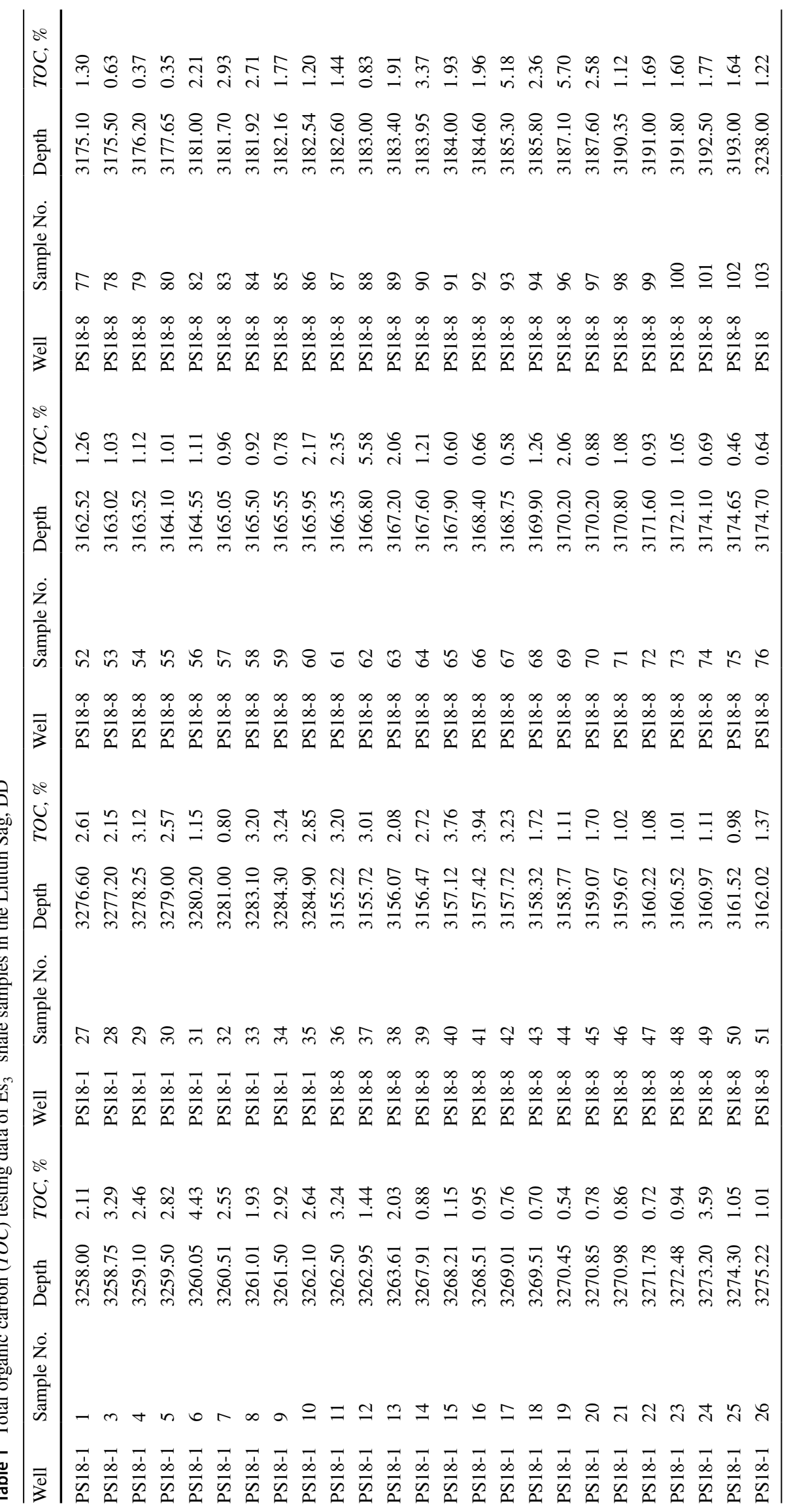




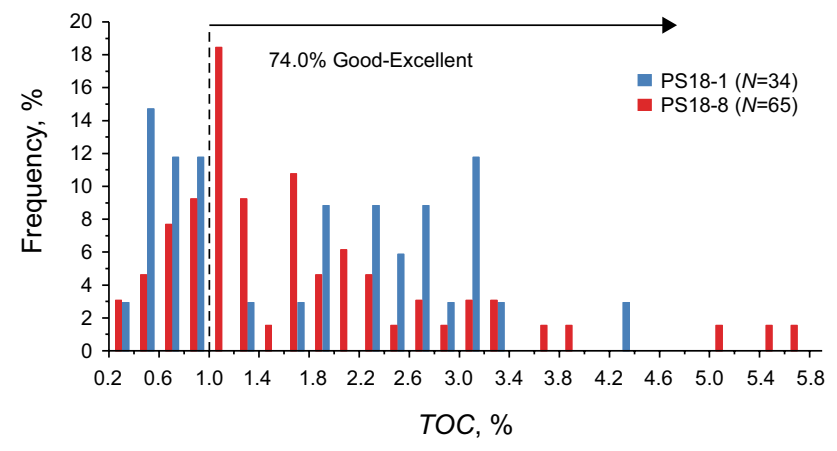

Fig. 4 Frequency histograms of total organic carbon (TOC), indicating that the $\mathrm{Es}_{3}{ }^{\mathrm{U}}$ shale is a set of good-excellent source rock. $\mathrm{N}$ indicates the number of samples. The evaluation criterion for goodexcellent source rocks was from Peters and Cassa (1994)

gradually decreases to $100 \mathrm{~m}$ at the north margin and to 75 $\mathrm{m}$ at the south margin (Deng et al. 2015). The average TOC value of Well PS18-1 is $1.98 \%$, and the variation is between $0.54 \%$ and $4.43 \%$, and the average value of Well PS18-8 is $1.75 \%$, with a range from $0.35 \%$ to $5.70 \%$ (Table 1 ), showing that the organic matter content of the shale varies considerably, but the lateral difference between these two wells is not significant.

\subsubsection{Organic matter type}

Maceral composition can be used to determine organic matter type of shale (Huang et al. 1984; Tissot and Welte 1984). Results show that the kerogen of the $\mathrm{Es}_{3}{ }^{\mathrm{U}}$ shale is on average composed of $59.4 \%$ sapropelinite (1.6-96.7 \%), $31.8 \%$ exinite $(0.3-89.7 \%), 8.3 \%$ vitrinite $(1.3-31.6 \%)$, and $0.5 \%$ inertinite $(0-3.0 \%)$ (Table 2). The hydrogen-rich amorphous content, accounting for an average of $57.3 \%$ $(0.9-95.5 \%)$, is predominantly translucent, nonhomogeneous, and flocculent (Fig. 5a, b, c, and d). The hydrogen-rich organic matter is amorphous, ranging in size from tens to hundreds of microns, and mainly exhibits a brown-yellow color under transmitted light (Fig. 5a, b, c, and d) and a bright-yellow color under the fluorescent microscope. The hydrogen-rich organic matters are the degradation products of aquatic organisms and algae under strong reducing conditions and have a significant petroleum generation potential (Burgess 1974; Rahman and Kinghorn 1995; Luo et al. 2017). Well-preserved elliptic alginite ranging from tens to hundreds of microns in size is found in the sapropelinite and exhibits a yellow-brown color under transmitted light (Fig. 5e, f, g, and h). Alginite is the most typical hydrogenrich microcomponent of sapropelinite and has a strong petroleum generation potential (Luo et al. 2017). Alginite is the degradation product of algae, and clear degradation traces can be seen (Fig. 5f). Axiohitic objects were also detected with SEM (Fig. 5i). These objects are also interpreted as algae fossils due to their shapes. Further energy spectrum analyses reveal that these fossils are rich in carbon and oxygen (Fig. 5j), indicating they are algae fossils (Tyson 1995; Qiu et al. 2015; İnan et al. 2016). The alginite content is low with an average of only $2.5 \%(0.3-11.3 \%)$ due to easy decomposition.

The exinite primarily consists of hydrogen-poor amorphous organic matter, sporinite, and cutinite, with average contents of $27.5 \%(0-88.5 \%), 2.2 \%(0-15.3 \%)$, and $1.8 \%(0-5.3 \%)$. The hydrogen-poor amorphous organic matter is formed from higher plants degradation, the microscopic characteristics of which are similar to hydrogen-rich amorphous organic matter, exhibiting flat, flocculent, and cloudy shapes (Fig. 5o), has a high petroleum generation potential but exhibits little fluorescence and some raised folds under the microscope. The precursors of sporinite (Fig. $5 \mathrm{k}, 1, \mathrm{~m}$, and $\mathrm{n}$ ) are primarily the chitinous tissues of higher plants containing higher fatty acids, alcohols, and lipids, generating petroleum by hydrolysis or reduction (Cao 1985). Vitrinite is mainly composed of telinite and euvitrinite, with average contents of $7.8 \%$ $(1.3-28.3 \%)$ and $0.4 \%(0-3.8 \%)$, respectively, which originates from wood fibers of higher plants, presenting a weak fluorescence and primarily generate natural gas. Telinite has a clear wood structure characterized by tubular cells, various conduits, and fibrous structures (Fig. 5p), and the structural clarity and transparency vary with the degradation degree. Inertinite is opaque under transmission light and has a dark brown to black-on-black angular shape, which is formed from the xylem fiber tissue of higher plants by fusainization, from which only trace amounts of natural gas are generated.

The maceral composition of the $\mathrm{Es}_{3}{ }^{\mathrm{U}}$ shale varies with depth. In detail, the shale samples from the thick and stable shale section are commonly rich in hydrogen-rich amorphous organic matter and poor in hydrogen-poor amorphous organic matter, but the opposite is true for the section with shale interbedded with evaporites (Fig. 6). This is because that the former section was mainly developed in deepwater environment, and the organic matter mainly originates from lower aquatic organisms and algae.

The TI values show that the organic matter of the shale from Well PS18-1 is dominated by type II kerogen, while the shale from Well PS18-8 is mainly composed of type I and II kerogen. The triangular chart further confirms that the organic matter of Well PS18-1 shale is entirely type II kerogen, while that of Well PS18-8 shale is mainly type I kerogen with a small amount of type II kerogen (Fig. 7). Lacustrine systems are highly sensitive to climate changes (Katz 1995), and the sequent changes in the balance between precipitation and evaporation further lead to the salinity variation, which in turn result in great variation in 


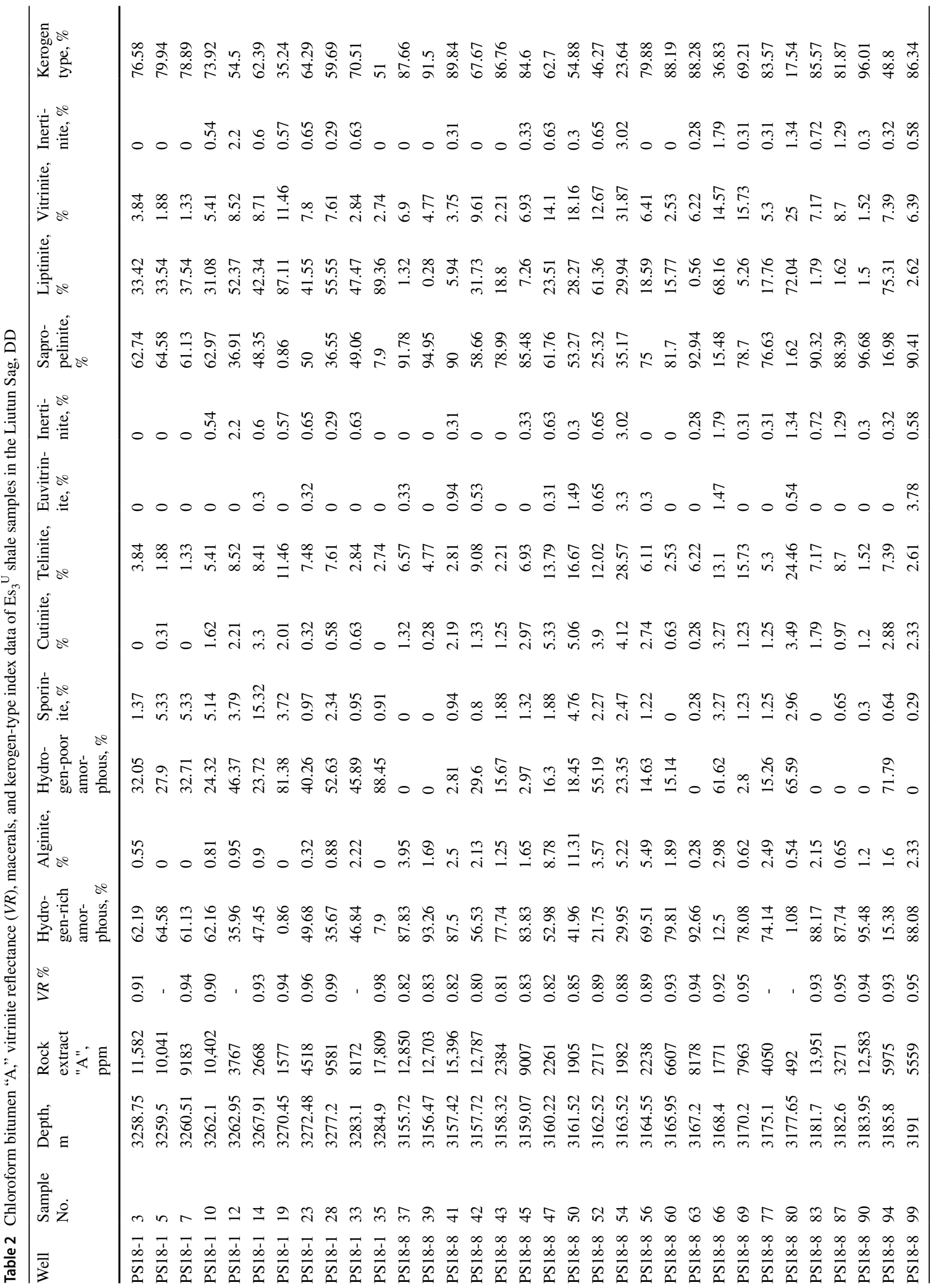



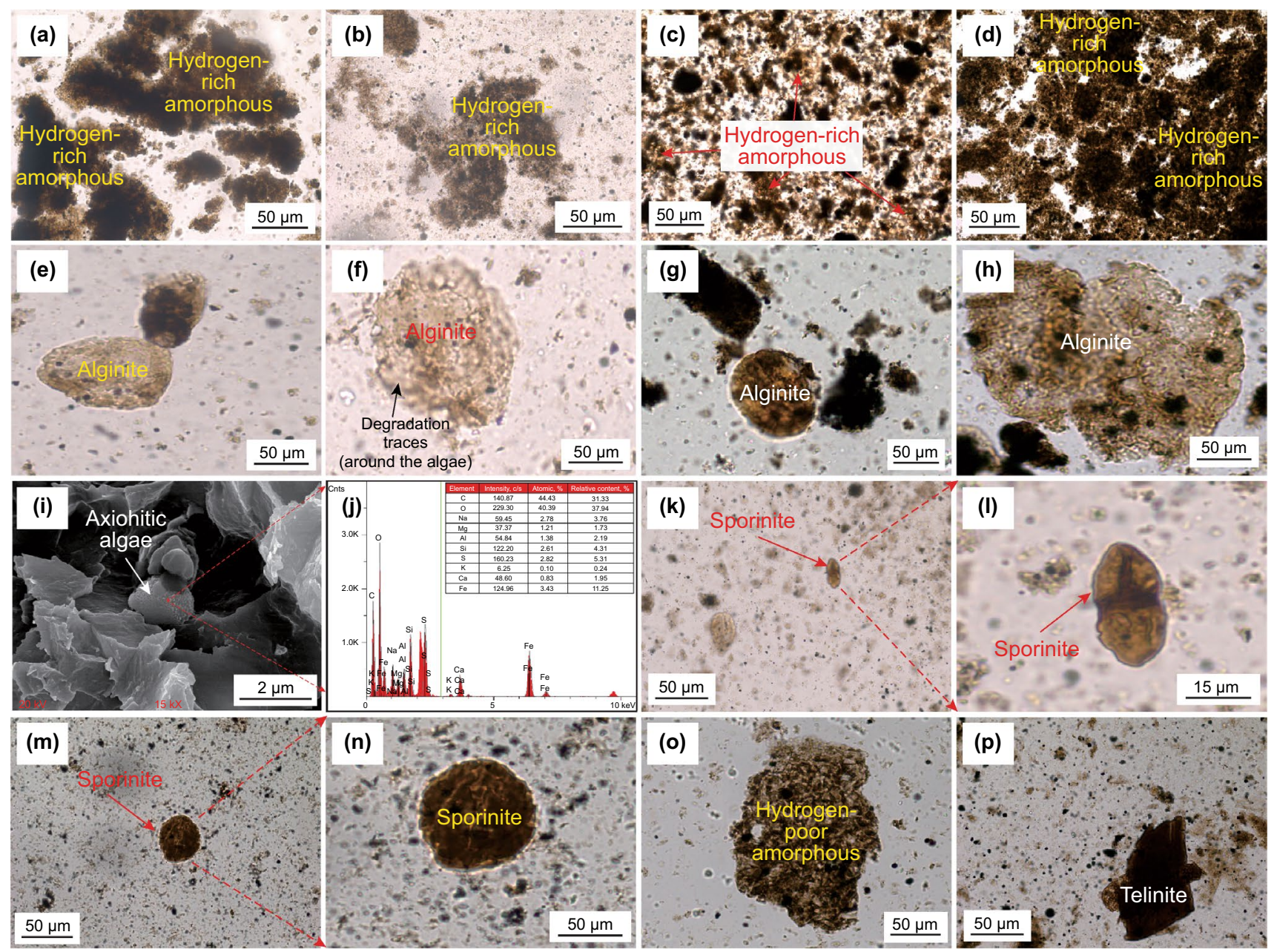

Fig. 5 Photomicrographs showing typical maceral composition of kerogen in $\mathrm{Es}_{3}{ }^{\mathrm{U}}$ shale of Liutun Sag, DD: a Well PS18-1, 3258.75m, $\times 640$, hydrogenrich amorphous; b Well PS18-1, 3259m, ×640, hydrogen-rich amorphous; c Well PS18-8, 3185m, ×640, hydrogen-rich amorphous; d Well PS18-8, 3191m, ×640, hydrogen-rich amorphous; e Well PS18-1, 3262.95m, ×640, alginite; f Well PS18-1, 3283.1m, ×640, alginite; g Well PS18-8, 3157.42m, ×640, alginite; h Well PS18-8, 3191m, $\times 640$, alginite; i Well PS18-8, 3193m, 20kV, alginite; j Well PS18-8, $3193 \mathrm{~m}$, energy spectrum analysis indicate that the axiohitic object in the (i) is algae; $\mathbf{k}$ Well PS18-1, 3258.75m, $\times 640$, sporinite; $\mathbf{l}$ Well PS18-1, 3258.75m, $\times 1020$, sporinite; m Well PS18-8, 3182.6m, $\times 640$, sporinite; $\mathbf{n}$ Well PS18-8, 3182.6m, $\times 1020$, sporinite; o Well PS18-8, 3175m, $\times 640$, hydrogen-poor amorphous; $\mathbf{p}$ Well PS18-8, 3157.72m, $\times 640$, telinite

the kerogen composition. As shown in Fig. 3, during $\mathrm{Es}_{3}{ }^{\mathrm{U}}$ deposition, thick and stable shale was developed in Well PS18-1 (3250-3285 m), while the shale in Well PS18-8 was frequently interbedded with evaporites (3167-3178 $\mathrm{m})$, indicating that although Wells PS18-8 and PS18-1 have similar structural settings, considerable differences exist in depositional environments. For example, the salinity of the depositional water in Well PS18-8 was much more varying and higher than that of Well PS18-1, resulting in significant variations in the kerogen types in Well PS18-8. Generally, in water with high salinity, the terrestrial higher plant input should be relatively small, while the lower halophilic aquatic organism input should be relatively great (Carbonel 1988; $\mathrm{Hu}$ et al. 2018b). Therefore, regarding the kerogen types, more shale samples of Well PS18-8 are type I, while few samples from Well PS18-1 are (Fig. 7).

\subsubsection{Thermal maturity}

Vitrinite reflectance $(V R)$ is a commonly indicator of thermal maturity (Tissot and Welte 1984). The $V R$ values of Wells PS18-1 and PS18-8 have averages of $0.94 \%(0.90-0.99 \%)$ and $0.88 \%(0.80-0.95 \%)$, respectively (Table 2$)$, showing that the shales in both wells are in the oil window. The thermal maturity of the shale in Well PS18-1 is slightly higher than that of the shale in Well PS18-8. 


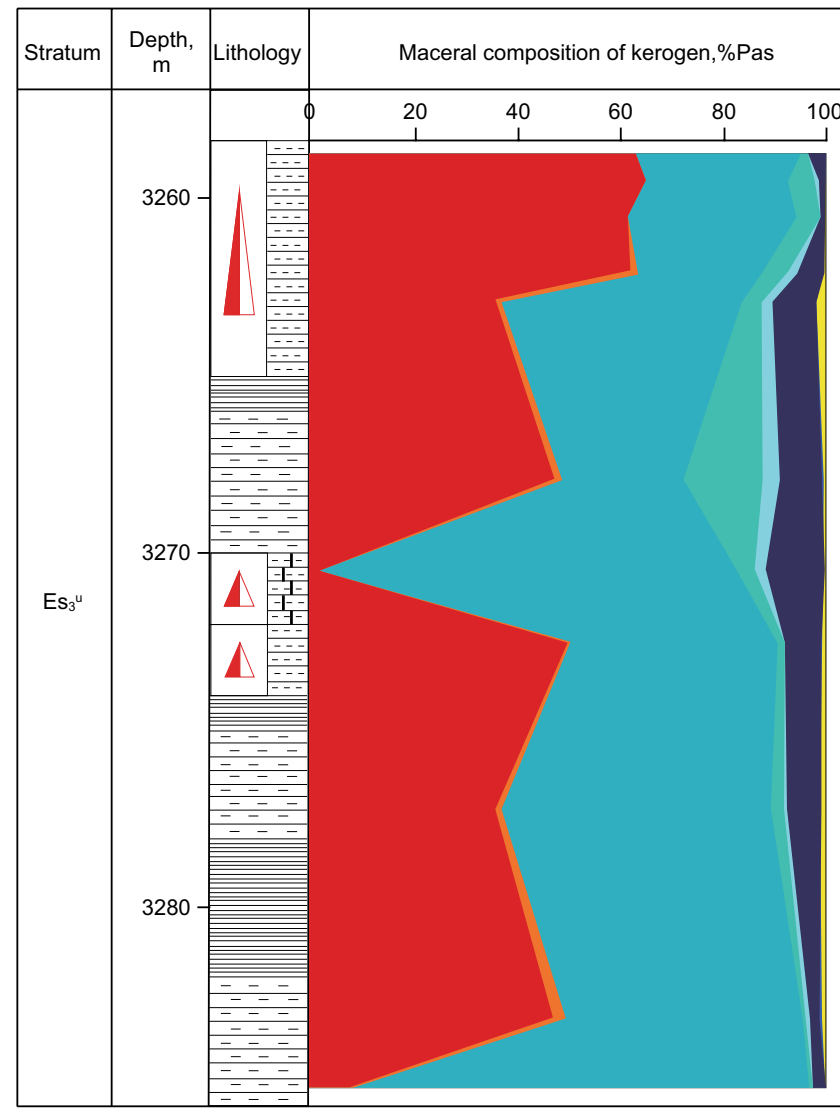

(a) PS18-1
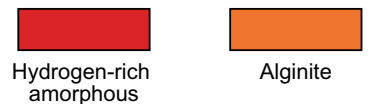

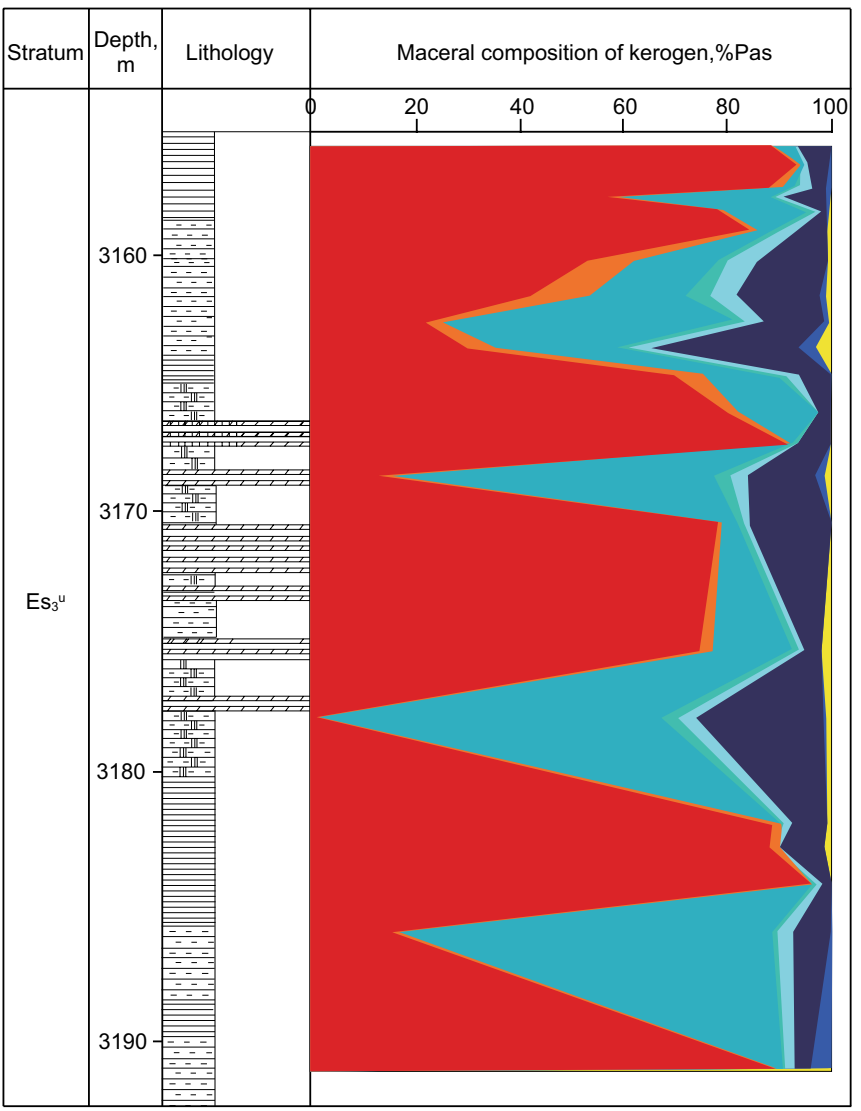

(b) PS18-8
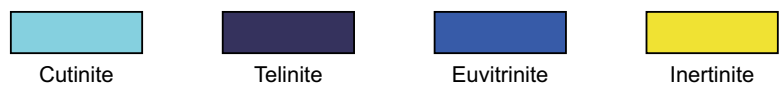

Fig. 6 Maceral composition profile of kerogens from $\mathrm{Es}_{3}{ }^{\mathrm{U}}$ shale in Liutun Sag, DD. \%Pas = Particle abundances of individual macerals. (The lithology legend refers to Fig. 3)

\subsubsection{Petroleum generation potential and shale oil content}

Factors controlling petroleum generation potential of shale include organic matter content, type, and thermal maturity. The shales in the DD have similar TOC contents, organic matter type, and thermal maturity to shale oil plays in other lacustrine basins in China. In comparison with the typical shale oil plays in the USA (Table 3), despite the lower TOC content and thermal maturity, the shale in the study is dominated by type I and II kerogens (Fig. 7). Besides, the gross thickness of the shales is much greater, with average and greatest gross thicknesses ranging from $500 \mathrm{~m}$ to $910 \mathrm{~m}$ and $800 \mathrm{~m}$ to $2610 \mathrm{~m}$, respectively (Wu et al. 2013; Duan et al. 2008). Therefore, the petroleum generation potential of the $\mathrm{Es}_{3}{ }^{\mathrm{U}}$ shale might be significant. In comparison, little difference exists in the organic matter contents and thermal maturity between the shales at Wells PS18-1 and PS18-8, but the latter exhibits a stronger oil-generating capacity due to significantly higher sapropelinite content (Fig. 7).
Oil content is an important parameter in evaluating oil resource (Jarvie 2008, 2012; Hu et al. 2018a; Wang et al. 2020). The rock extract "A" content can directly assess shale oil content. The rock extract "A" contents of the shale samples from both wells range between $0.5-17.8 \times 10^{3} \mathrm{ppm}$ with a mean of $7.1 \times 10^{3} \mathrm{ppm}$ (Table 1 ). The rock extract "A" contents of Well PS18-1 range from 1.6 to $17.8 \times 10^{3} \mathrm{ppm}$ with an average of $8.1 \times 10^{3} \mathrm{ppm}$, while the extract " $\mathrm{A}$ " contents of Well PS18-8 range from 0.5 to $15.4 \times 10^{3} \mathrm{ppm}$ with a mean of $6.7 \times 10^{3} \mathrm{ppm}$. Further analyses show that the oil content of the $\mathrm{Es}_{3}{ }^{\mathrm{U}}$ shale has a positive correlation with TOC content (Fig. 8a) with a slope of $2248.1(R$-squared $=0.9063)$, indicating that the higher the TOC is, the higher the shale oil content is. The correlation between the oil content and the kerogen TI is slightly positive correlated with a slope of 11.0 $(R$-squared $=0.4256)($ Fig. $8 \mathrm{~b})$, revealing that the organic matter type also controls the oil content, and the larger the kerogen TI is, the higher the shale oil content is. However, the effect of the kerogen type on oil content is much less 


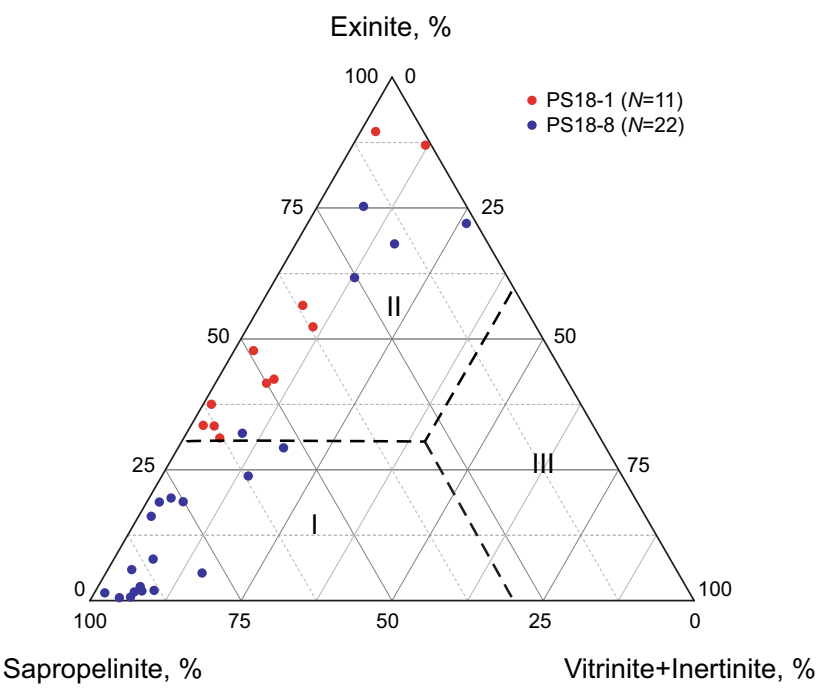

Fig. 7 Ternary Diagram of sapropelinite, exinite, vitrinite, and inertinite in $\mathrm{Es}_{3}{ }^{\mathrm{U}}$ shale, Liutun Sag, DD, indicating that the kerogen of Well PS18-1 is type II kerogen and Well PS18-8 is mainly type I kerogen with a small amount of type II kerogen, respectively. $N$ indicates the number of samples. (The classification diagram refers to Wang et al. (2015a))

than TOC content. This conclusion can also be confirmed by the observation that, although the kerogen type of the shale at the Well PS18-8 is more oil-prone than that of the Well PS18-1, the shale oil contents of the Well PS18-8 are smaller than that of the Well PS18-1, which is mainly due to the smaller TOC of the shale at the Well PS18-8.

In summary, although the petroleum generation potential of the shale at Well PS18-8 is relatively greater than that of the shale at Well PS18-1, the shale oil content of the latter well is slightly greater due to the slightly greater TOC. Therefore, petroleum generation potential is not a key factor affecting the shale oil enrichment between the two wells.

\subsection{Reservoir volume}

\subsubsection{Fractures}

Fractures are faults without significant displacement and effective reservoir volume for shale oil (Ferrill et al. 2014). Tectonic, overpressure, and diagenetic fractures were identified in the study by core samples, fluorescence microscopy, and FE-SEM observations.

Tectonic fractures refer to those formed by or associated with the local tectonics. Tectonic activity was common in the DD (Chen et al. 2013) and enabled the formation of various derived fractures near the marginal faults (Wang et al. 2015a). Tectonic fractures include tension, shear, and compression fractures, and the former two were primarily developed in the $\mathrm{Es}_{3}{ }^{\mathrm{U}}$ shale. Tension fractures are formed under tensile stress and not fracturing through minerals when extending, exhibiting curved extension planes and profiles (Fig. 9a and b), which play important roles in connecting different types of fractures. The tension fractures in the study are not only related to the tectonics but also the evaporites. In the $\mathrm{Es}_{3}{ }^{\mathrm{U}}$ shale, the evaporites are interbedded with shale (Fig. 3). Differential compaction and irregular plastic flow of evaporites easily occur due to difference in density between evaporites and shales. As shale is clearly more brittle than salt, when the pressure caused by differential compaction or irregular plastic flow of the evaporites exceeds the critical rupture pressure of the shale, the tension fractures form. In the $\mathrm{Es}_{3}{ }_{3}^{\mathrm{U}}$ shale, seventy percent of tension fractures are filled with gypsum, calcite, halite, and asphalt (Fig. 9a and b), and the remaining tension fractures are open fractures in which oil impregnation is common (Fig. 9c and d), as a result of the extensively developed evaporites. Under the influence of tectonic activity and differential compaction, the induced tension fractures in the shale interbedded with the evaporites were very easily filled by the flowable evaporites. However, in the thick shale, the induced tension fractures were filled by the oil generated from the adjacent shales, and the accumulated oil further promoted the preservation of fracture space. Shear fractures are mainly formed by shear stress, generally open and having straight and flat planes and profiles (Fig. 9e, f, g, and h). X-shaped conjugate joints (width: $1-5 \mathrm{~mm}$ ) can also be identified (Fig. 9g) and were filled with oil (Fig. 9g and h).

Diagenetic fractures are microfractures formed due to diagenetic compaction (Luo et al. 2015). Interlayer bedding, dissolution, and shrinkage fractures are commonly observed in the $\mathrm{Es}_{3}{ }^{\mathrm{U}}$ shale. Interlayer bedding fractures are the most common fractures and develop near lithological interfaces (Fig. 9i, j, and k), and the openings are usually small and were filled (Fig. 91 and m). Dissolution fractures are enlarged primary fractures or newly formed by differential dissolution along the lamina, due to different mineral compositions and particle arrangements between lamina (Luo et al. 2015), which are mostly parallel to rock surfaces (Fig. 9n). Shrinkage fractures are commonly formed by change of facies or thermal contraction of different minerals, or in the coring and sample preparation process, which are usually short and have good connectivity and various apertures, with some filled with illite and halite (Fig. 9o, p, q and r).

Overpressure fractures refer to fractures at a certain depth and under a closed pressure system. In shales, these fractures form by overpressure due to hydrocarbon generation, clay mineral dehydration, hydrothermal activity, or authigenic mineral precipitation (Wang et al. 2015b). The $\mathrm{Es}_{3}{ }^{\mathrm{U}}$ shale is a set of good to excellent petroleum source rocks within oil window. Petroleum generation in these source rocks can cause overpressure (Luo et al. 2015, 2016). The extensively 


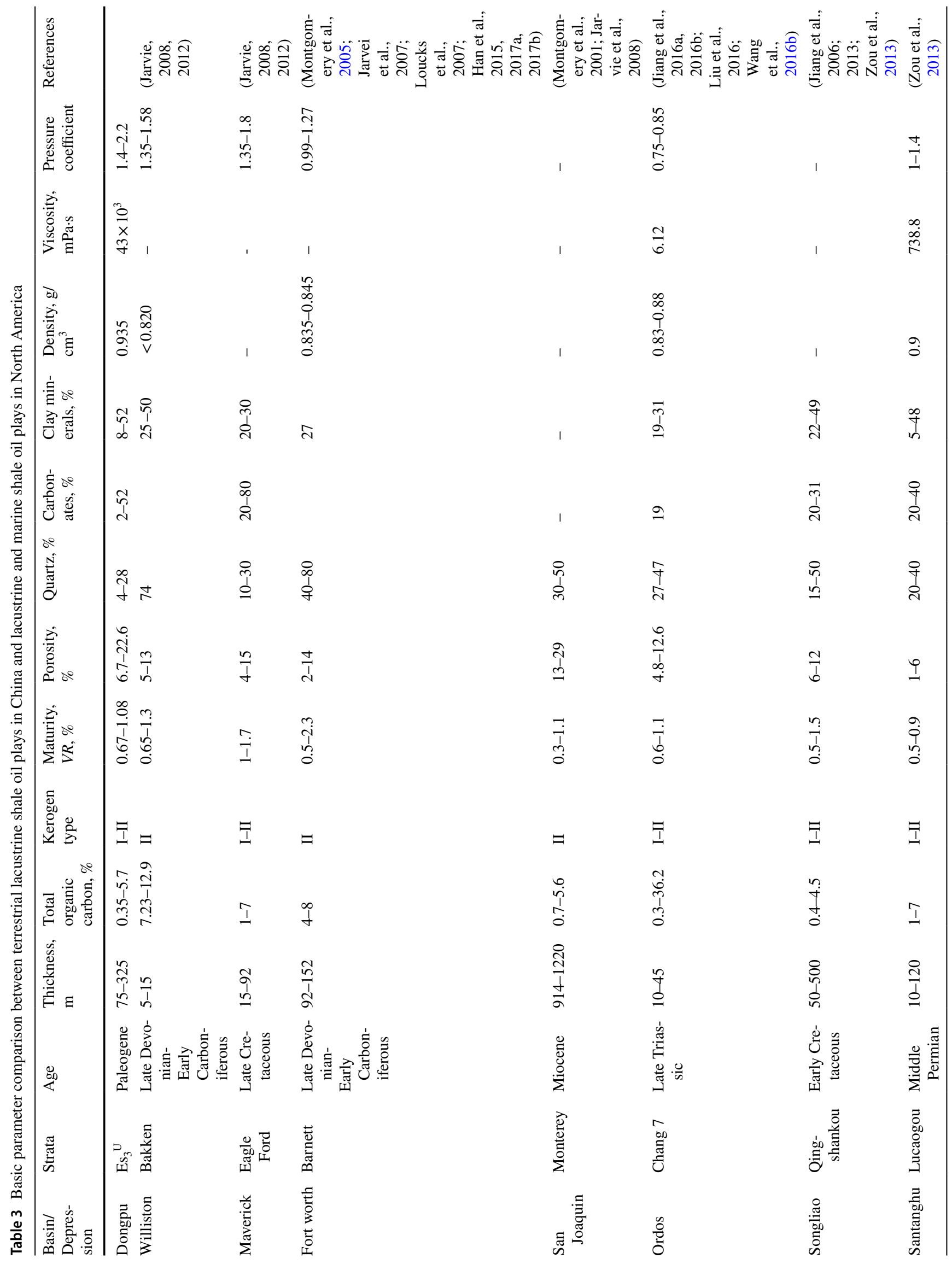




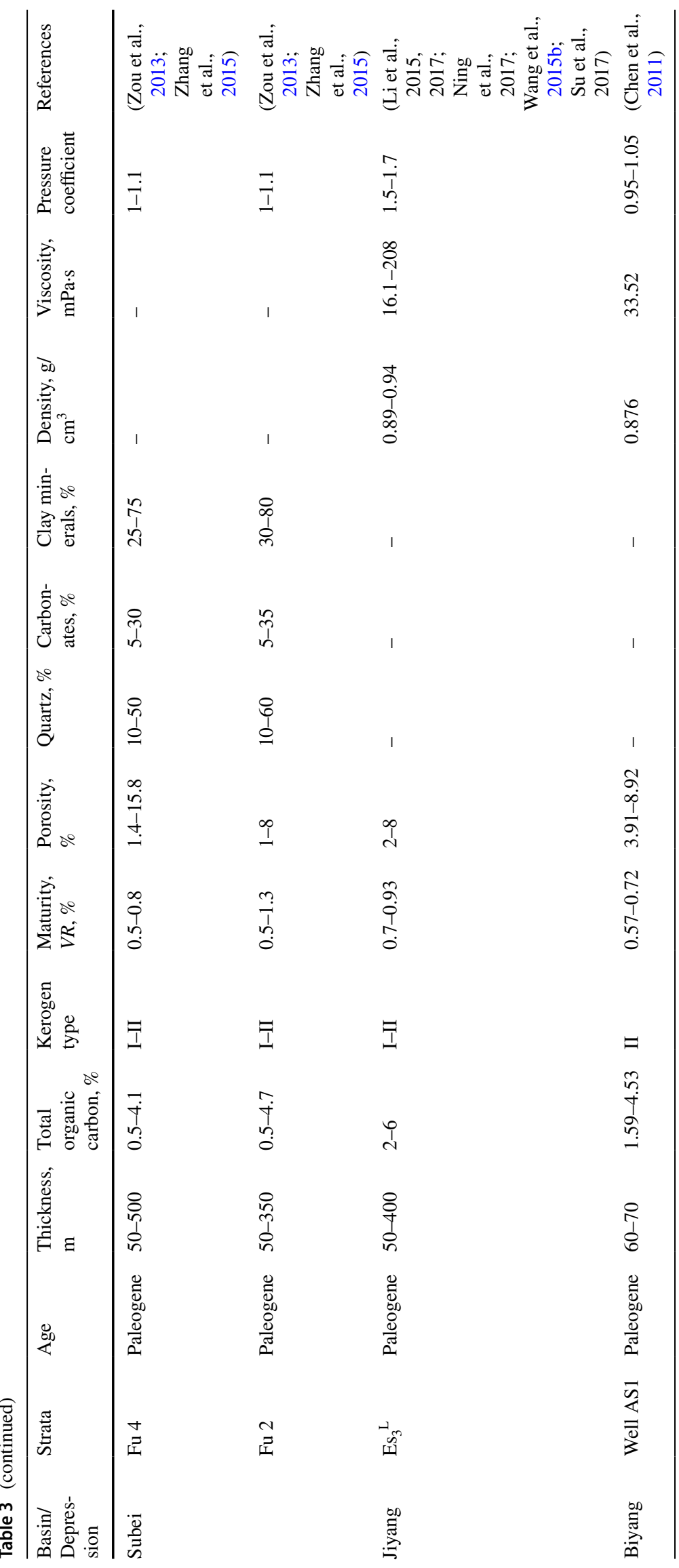



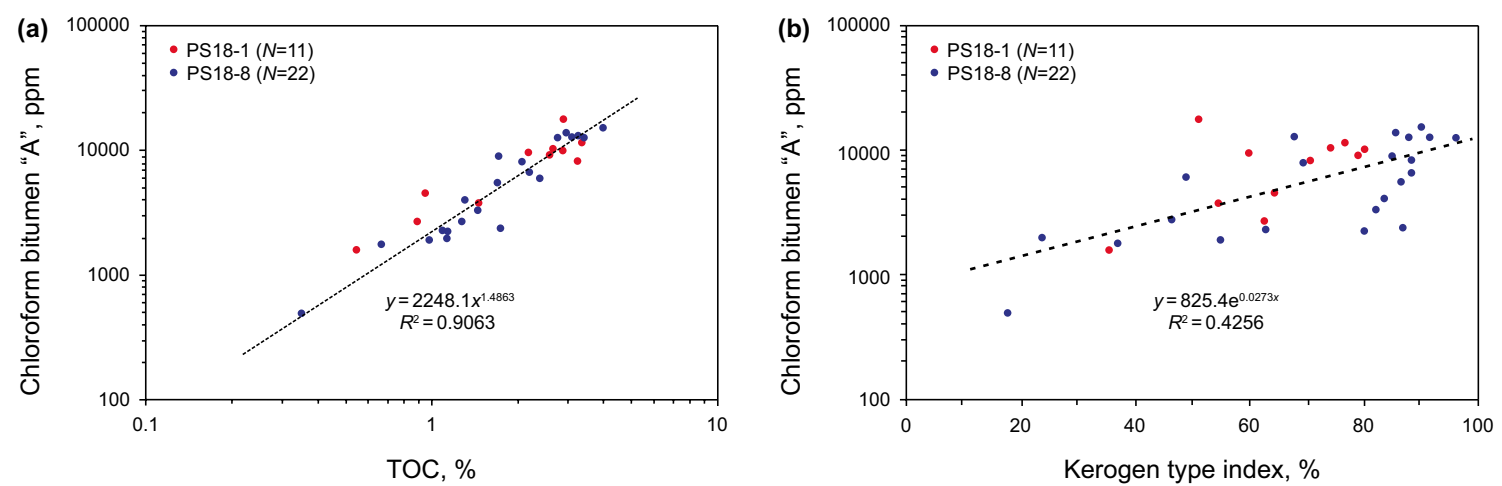

Fig. 8 Correlation between rock extract "A" content and a TOC, and b kerogen type index in $\mathrm{Es}_{3}{ }^{\mathrm{U}}$ shale, Liutun Sag, DD. $N$ indicates the number of samples
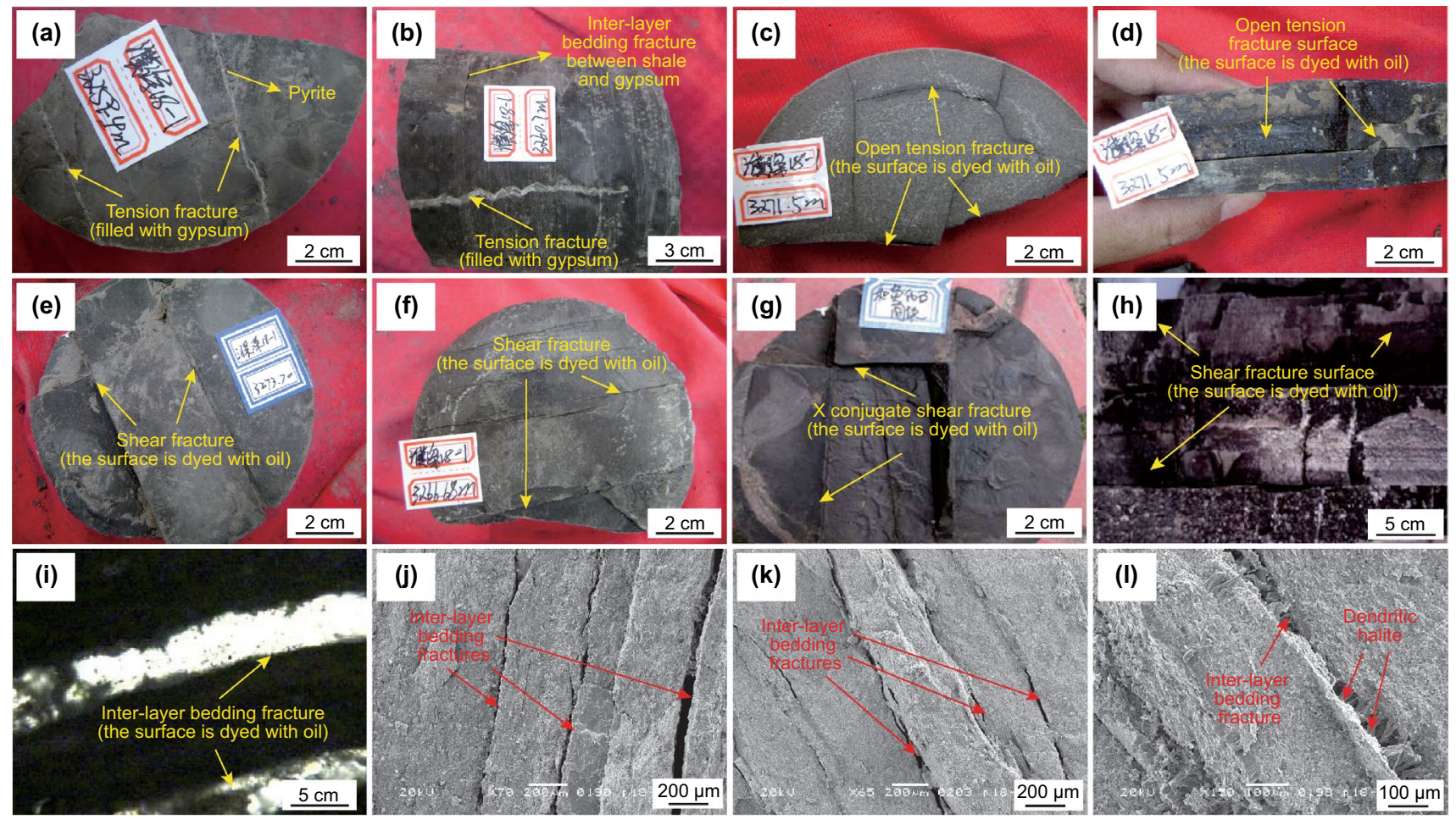

Fig. 9 Photos of cores and SEM images showing typical fracture characteristics of $\mathrm{Es}_{3}{ }^{\mathrm{U}}$ shale in Liutun Sag, DD. a Well PS18-1, 3259.4m, tectonic fractures and fissures are integrated and filled with gypsum and pyrite; b Well PS18-1, 3260.7m, tectonic fractures and fissures are integrated and filled with gypsum; c-d Well PS18-1, 3271.5m, tectonic fractures and diagenetic fractures, the surface of which is dyed with oil; e Well PS18-1, 3273.7m, tectonic fractures, the surface of which is dyed with oil; f Well PS18-1, 3266.68m,vertical tectonic fractures developed in groups and the surface is dyed with oil; g Well PS18-1, 3273.6m, X-type conjugate shear fractures, the surface of which is dyed with oil; h Well PS18-1, 3270.45m, shear fractures, the surface of which bears asphalt; i Well PS18-1, 3265.78m, inter-lamina micro-fractures, yellow fluorescence indicates the filling of oil in the micro-fractures; $\mathbf{j}$ Well PS18-8, 3185m, lamination development, lamina fractures present; $\mathbf{k}$ Well PS18-8, 3187.8m, micro-lamination development, inter-lamina fractures present; l Well PS18-8, 3186m, fractures are filled with dendritic halite crystals; $\mathbf{m}$ Well PS18-8, 3187.8m, lamination development, lamina fractures present; $\mathbf{n}$ Well PS18- 1, 3182m, diagenetic dissolution fractures; $\mathbf{o}$ Well PS18-8, 3187.8m, flaky illite showing the scale structure, developed with shrinkage fractures; p Well PS18-8, 3161.2m, flaky illite adhered to the surface of halite aggregation, developed with shrinkage fractures; q Well PS18-8, 3163.22m, flaky and silky illite and halite aggregation, developed with shrinkage fractures; $\mathbf{r}$ Well PS18-8, 3187.8m, shrinkage fractures are filled with halite aggregation; s Well PS18-1, 3289.8m, natural hydraulic fractures, the surface of which is wormlike with uncertain distribution directions, fractures are open; $\mathbf{t}$ Well PS18-8, 3169m, natural hydraulic tension fractures, short and thick, thick in the middle and thin on both ends; $\mathbf{u}$ Well PS18-1, 3260.7m, plane polarized light photograph; v Well PS18-1, 3260.7m, ultraviolet light-excited fluorescent photograph showing the oil inclusion with yellow and blue-white fluorescence; w Well PS18-8, 3156.45m, plane polarized light photograph; x Well PS18-8, 3156.45m, ultraviolet light-excited fluorescent photograph showing the oil inclusions with yellow fluorescence 

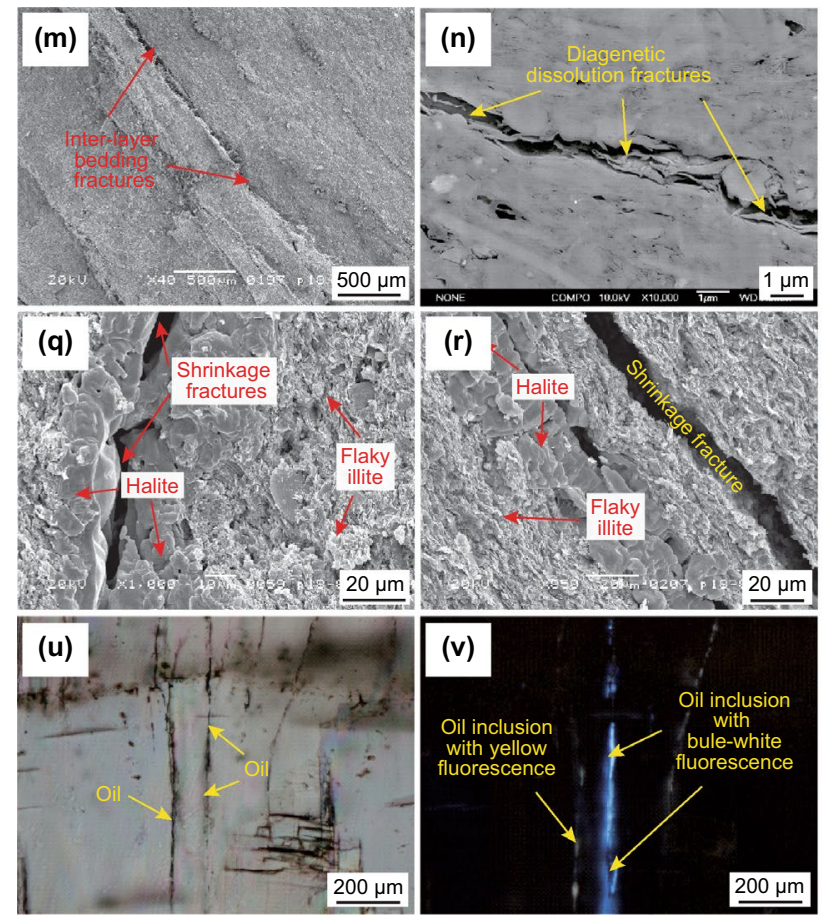
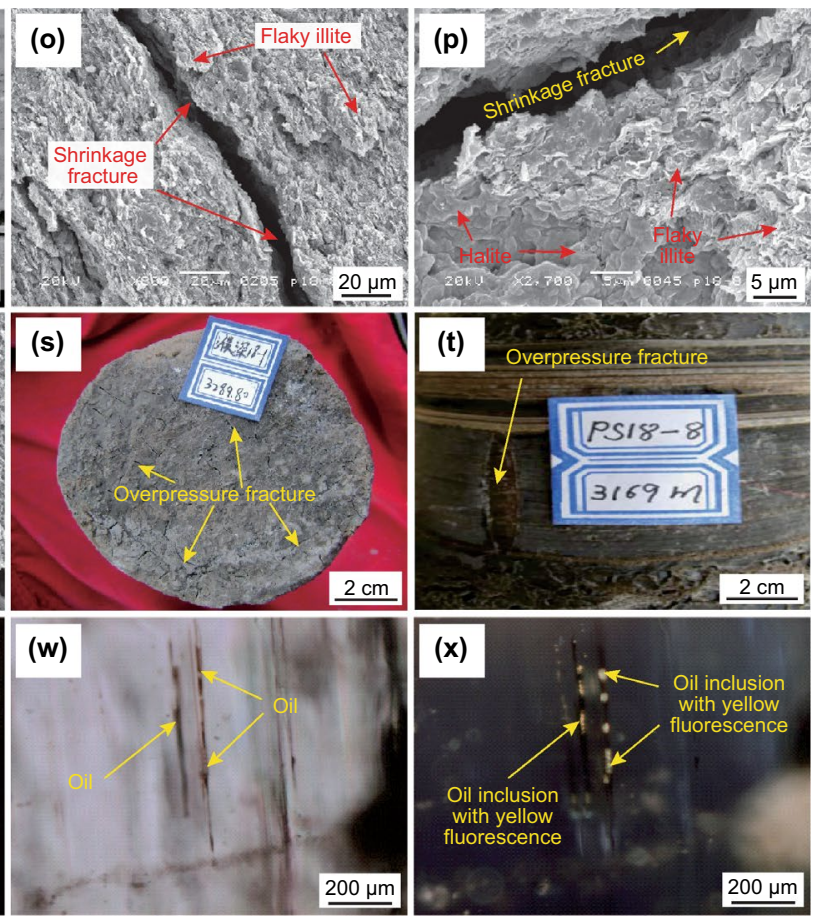

Fig. 9 (continued)

developed gypsums preserve the overpressure introduced by petroleum generation (Luo et al 2016). The shale will rupture when the overpressure reaches the critical fracturing pressure, forming overpressure fractures. Generally, overpressure fractures are randomly distributed in wormlike shapes in the shale plane with no preferred orientation (Fig. 9s). Some are short, wide in the middle and thin at the tips, exhibiting a spindle-like shape (Fig. 9t). Most overpressure fractures are constrained by layered gypsum. However, when the gypsum laminae are thin, they can also be cut by overpressure fractures (Fig. 9t).

Previous studies have shown that the fractures in the $\mathrm{Es}_{3}{ }^{\mathrm{U}}$ shale are mainly tectonic and overpressure fractures with a few diagenetic fractures (Luo et al. 2015). This study found that diagenetic fractures are well developed despite their small micron scale (Fig. 9i-r). The large number of tectonic and overpressure fractures commonly cut through the diagenetic fractures, enabling the formation of threedimensional fracture networks, which significantly improve seepage capacity (Fig. 9a-h and s-t). Therefore, as for the reservoir volume, the contribution of the diagenetic fractures cannot be ignored in the $\mathrm{Es}_{3}{ }^{\mathrm{U}}$ shale oil play.

As shown in Section 4.1.4, the TOC content controls the shale oil enrichment, mainly because the organic matter not only generates oil but also absorb it. However, compared to the absorbed oil, the oil accumulated in the shale fractures could be either generated from in situ shale or migrated from adjacent shale, which is mainly movable oil. The abovementioned two enrichment mechanisms are completely different. In this study, without anthropogenic fracturing, a shale oil yield of $430 \mathrm{~m}^{3} / \mathrm{d}$ was achieved in Well PS18-1, indicating that most of the produced oil should be movable oil in the fractures. The widely distributed oil inclusions in the fractures further prove it (Fig. $9 \mathrm{u}, \mathrm{v}, \mathrm{w}$, and $\mathrm{x}$ ). Therefore, the reservoir volume available for shale oil is mainly determined by the degree of fracture development, which is usually evaluated by fracture density (Curtis 2002). The average fracture densities of the shale in Well PS18-1 are 2.79, 4 , and 4 stripes/meter in the depth intervals of 3220-3290 $\mathrm{m}, 3258-3260 \mathrm{~m}$, and 3276-3278 m, respectively, and the maximum fracture density is 7 stripes/meter (Fig. 10a). On the contrary, the average fracture density of the interval of $3140-3190$ m of Well PS18-8 is 0.72 stripes/meter, and the maximum fracture density is only 2 stripes/meter at 3157 $\mathrm{m}, 3171 \mathrm{~m}$, and $3182 \mathrm{~m}$ (Fig. 10b). The higher fracture density of the shale in Well PS18-1 was mainly induced by two factors: lithology difference and formation pressure difference. Firstly, as shown in Fig. 3, compared with the interval of interest (3250-3285 m) in Well PS18-1, the interval of interest (3155-3195 m) in Well PS18-8 is characterized by evaporites that are thin and interbedded with shale, which greatly enhance the plasticity of the strata. Therefore, less fractures would form in the Well PS18-8 under similar formation pressure. Secondly, the higher the formation pressure is, the more fractures there are. In comparison, the measured MDT formation pressure coefficient of Well PS18-1 is 2.2, 

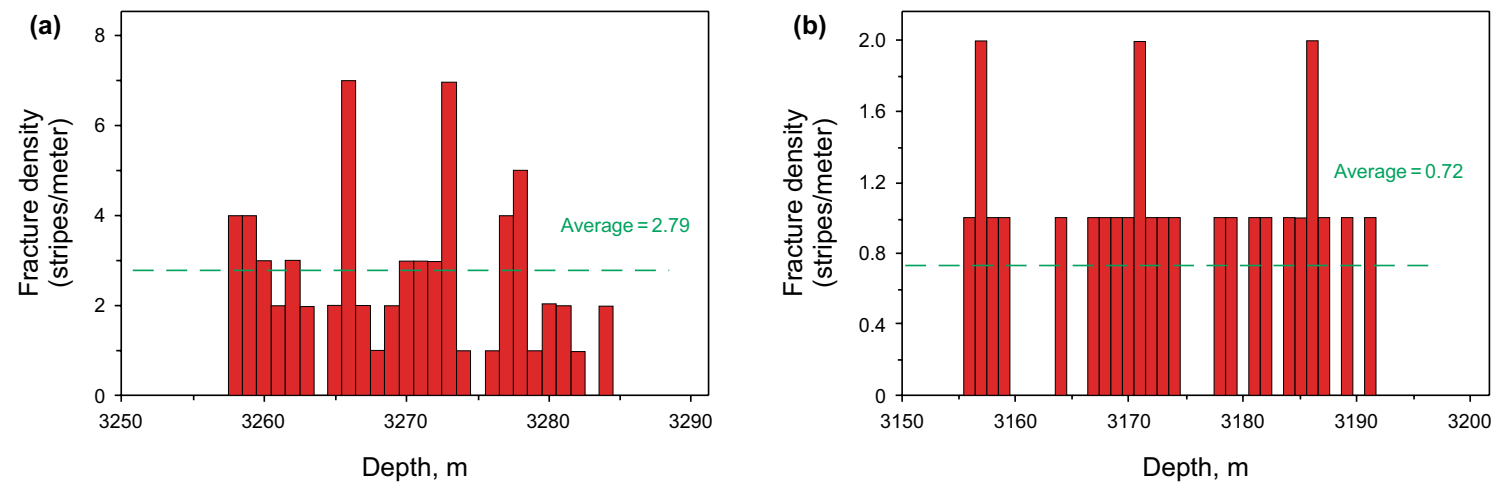

Fig. 10 Fracture development density diagram of $\mathrm{Es}_{3}{ }^{\mathrm{U}}$ saline lacustrine shale in a Well PS18-1 and b Well PS18-8 in the Liutun Sag, DD, indicating that the fracture development density of shale in Well PS18-1 is significantly higher than that in Well PS18-8

which is significantly greater than that of Well PS18-8, with only 1.4. Therefore, due to the greater plasticity and lower formation pressure of the shale intervals, significantly less fractures were developed in the Well PS18-8. In view of the positive correlation between the fracture density and reservoir volume, the reservoir volume of the shale at Well PS18-1 should be dramatically greater than that at Well PS18-8, making the former area more conducive to shale oil enrichment.

\subsubsection{Pores}

The FE-SEM and energy spectrum analyses show that the pores in the $\mathrm{Es}_{3}{ }^{\mathrm{U}}$ shale samples include interparticle (intercrystalline), intraparticle (intracrystalline), and organic matter pores. Interparticle (intercrystalline) pores are mainly intercrystalline pores (Fig. $11 \mathrm{a}-\mathrm{g}$ ), with a small proportion of interparticle residual pores (Fig. $11 \mathrm{~g}$ ). These pore features are mainly related to the hypersaline and strong reducing environment during deposition. Compared with marine shales, the $\mathrm{Es}_{3}{ }^{\mathrm{U}}$ shale has a relatively lower content of rigidgrain minerals such as quartz but a relatively higher content of clay and saline minerals, leading to a dispersion of the rigid grains among the clay minerals and organic matter, and impeding the formation of a grain-supported structure (Wang et al. 2016a). Therefore, the interparticle pores are less developed and can be found between pyrite and halite in a few samples (Fig. 11a-f). Furthermore, the abundant clay and saline minerals are easily subjected to dissolution by organic acids released from petroleum generation and anthropogenic dissolution during drilling and sampling processes, resulting in many intercrystalline pores. To minimize the impact of anthropogenic dissolution, the shale samples were placed in cool and dry conditions and the drying cutting technique was applied during sample preparation. The results show that, as shown in Fig. 11a-f, numerous minerals were adsorbed around most of the salt pores, indicating that most of the pores were formed geologically. In the $\mathrm{Es}_{3} \mathrm{U}$ shale, pores with different geometries were developed, which were collectively controlled by the primary pore geometry and diagenesis. The linear shape pores were mainly formed between large halite crystals and clay minerals (Fig. 11b and d). The elliptical-triangular pores represent the remaining pore space between particles that have been subjected to compaction and cementation (Fig. 11a and e). The pores with internal paper-house microstructures are usually open (Fig. 11c and f) and create connectivity among pores. The pore size of the intercrystalline pores mainly ranges between 2 and $40 \mu \mathrm{m}$. Some pores have good connectivity, contributing to the formation of an effective pore network and providing microchannels for the transportation and accumulation of petroleum, which is conducive to shale oil enrichment.

Intraparticle (intracrystalline) pores refer to the pores developed within particles. In this study area, these types of pores mostly formed in the later stage of diagenesis, and few are primary (Wang et al. 2016b). The $\mathrm{Es}_{3}{ }^{\mathrm{U}}$ shale has a low content of rigid-grain minerals but a high content of carbonates, clay, and saline minerals, which are susceptible to dissolution and the subsequent formation of intraparticle (intracrystalline) pores (Wang et al. 2015a, 2016a). The intraparticle (intracrystalline) pores mainly include halite (Fig. 11d, h, and l) and anhydrite intracrystalline pores (Fig. 11j and k), followed by moldic pores (Fig. 11i), dissolution pores between the framboidal pyrites (Fig. 11b), and pores within the calcite (Fig. $11 \mathrm{~m}$ ). The moldic pores formed from the partial dissolution of halite particles. The diameters of the intraparticle (intracrystalline) pores range from 1 to $50 \mu \mathrm{m}$.

Organic matter pores are intraparticle pores that develop in organic matter. The formation, distribution, and size of these pores are related to the organic matter content, type, and thermal maturity of the shale (Loucks et al. 2012; Wang et al. 2016b). The organic matter pores in this study are often connected by shrinkage fractures, dissolution pores, 

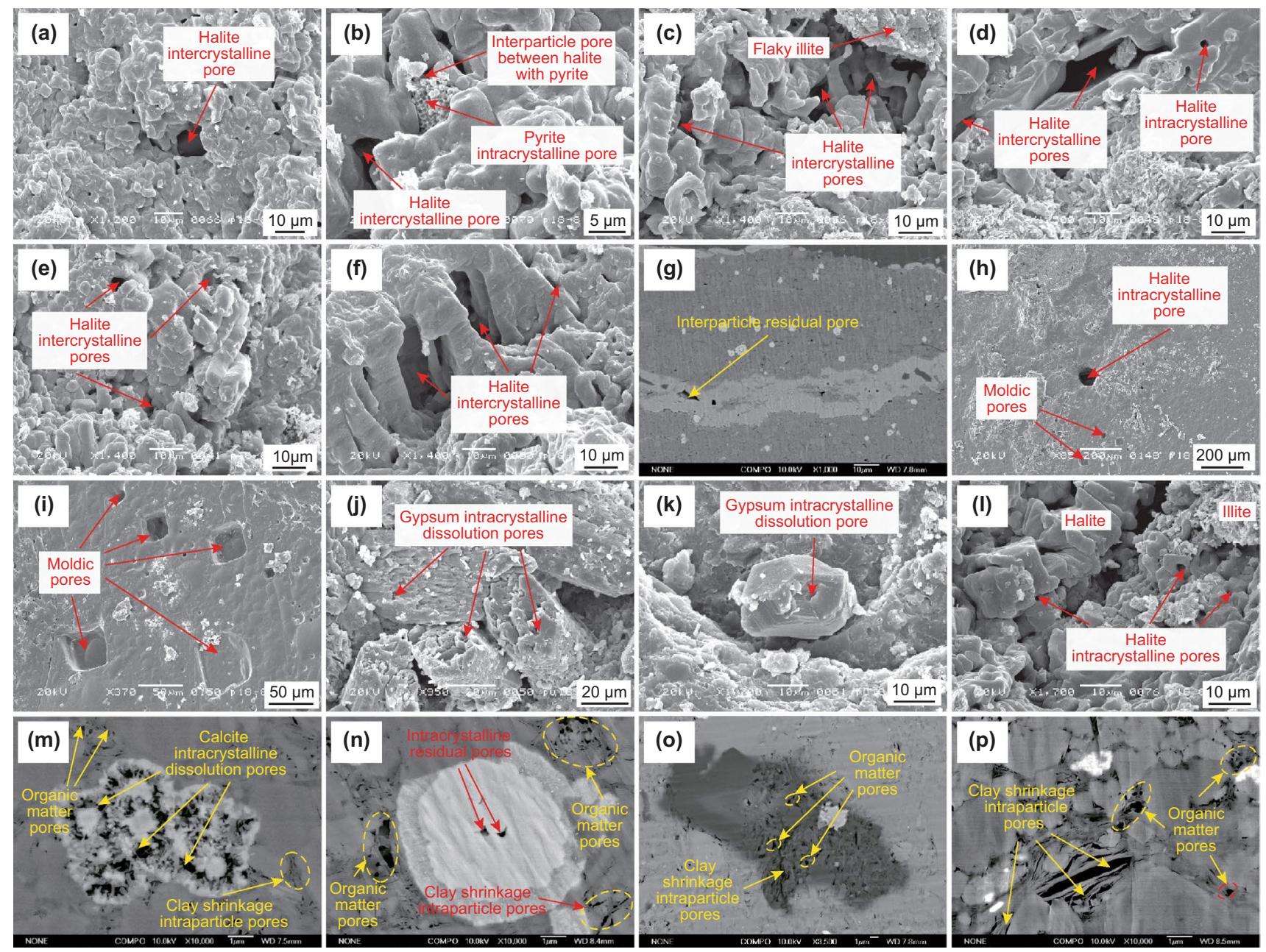

Fig. 11 SEM images showing typical pore characteristics of $\mathrm{Es}_{3}{ }^{\mathrm{U}}$ shale in the Liutun Sag, DD. a Well PS18-8, 3164m, halite aggregation and microfractures, developed with interparticle dissolution pores and intraparticle dissolution pores; b Well PS18-8, 3164m, a small number of microcrystal pyrite crystals present among halite crystals, developed with interparticle dissolution pores and intraparticle dissolution pores; c Well PS18-8, 3162.23m, halite aggregation and micro dissolution pores, developed with interparticle dissolution pores; $\mathbf{d}$ Well PS18-8, $3161.2 \mathrm{~m}$, halite aggregation and micro dissolution pores, developed with interparticle dissolution pores and intraparticle dissolution pores; $\mathbf{e}$ Well PS18-8, 3160.1m, halite aggregation and micro dissolution pores, developed with interparticle dissolution pores; f Well PS18-8, 3162.23m, halite crystals and dissolution pores, developed with interparticle dissolution pores; $\mathbf{g}$ Well PS18-8, 3182m, developed with interparticle residual pores; h Well PS18-8, 3177.1m, halite exhibits a hardened shape and the presence of circular intraparticle dissolution pores; i Well PS18-8, $3177.1 \mathrm{~m}$, halite crystals form mold pits after dissolution; j Well PS18-1, 3280.4m, anhydrite surface is dissolved, developed with intracrystalline dissolution pores; $\mathbf{k}$ Well PS18-1, 3280.4m, surface of angular anhydrite crystals is dissolved, developed with intracrystalline dissolution pores; $\mathbf{l}$ Well PS18-8, 3165.1m, halite aggregation and dissolution pores, developed with intraparticle dissolution pores; m Well PS18-1, 3267m, developed with intracrystalline residual pores, organic matter pores, and intra-organic matter contraction pores; $\mathbf{n}$ Well PS18- 1, 3267m, intra-organic matter shrinkage pores; o Well PS18-1, 3263.61m, developed with organic matter pores; $\mathbf{p}$ Well PS18-8, 3167.2m, developed with organic matter dissolution pores

and microfractures, exhibiting strip-like or network-like shapes. For example, interconnected pores are introduced by the connection between organic matter pores and intercrystalline pores formed by clay mineral shrinkage (Fig. 11n and o) as well as that between other organic matter pores and intraparticle pores formed by clay mineral dissolution (Fig. 11p). Due to oil adsorption of the organic matter, the organic matter pores are very important for shale oil enrichment. Organic matter pores are less developed in the $\mathrm{Es}_{3}{ }^{\mathrm{U}}$ shale and are generally small, which might be related to the low thermal maturity. Generally, the organic matter pores begin to form when the $V R$ of the kerogen reaches $0.8 \%$ (Reed et al. 2012; Katz and Arango 2018), such as the Mississippian Barnett Shale and the Toarcian Posidonia Shale in Lower Saxony, Germany (Loucks et al. 2009; Han et al. 2014). At present, the $V R$ average of the $\mathrm{Es}_{3}{ }^{\mathrm{U}}$ shale is merely $0.9 \%$, indicating a relatively low thermal maturity, so the organic matter pores in this shale are less developed. 


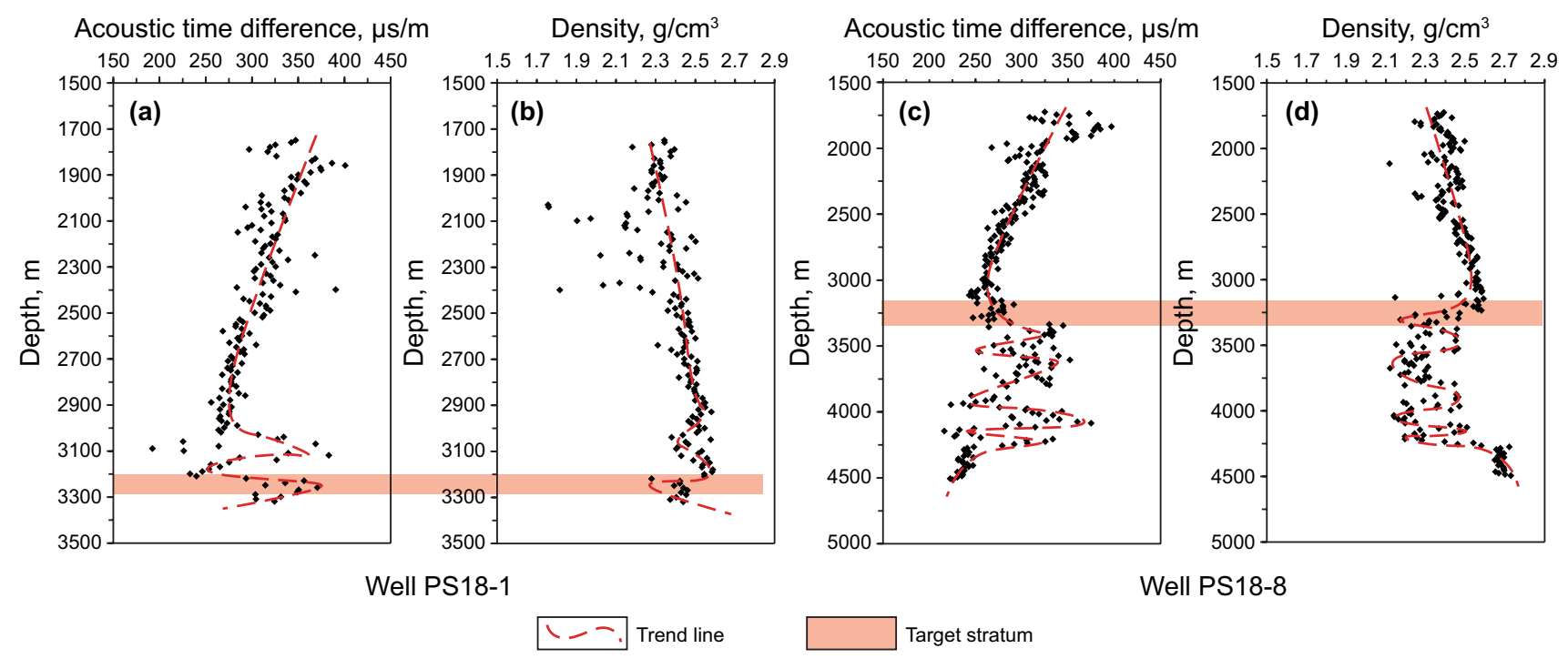

Fig. 12 Profiles of depth vs. logging data: a acoustic time difference of Well PS18-1; b mud density of Well PS18-1; c acoustic time difference of Well PS18-8; $\mathbf{d}$ mud density of Well PS18-8; showing the abnormal high porosity and strong overpressure

Overall, intercrystalline and intracrystalline pores predominate in the $\mathrm{Es}_{3} \mathrm{U}$ shale, while organic matter pores are less developed. Comparative analyses indicate little pore difference exist in the shales between Wells PS18-1 and PS18-8. The average surface porosity tested by liquid saturation method of five shale samples from Well PS18-1 is $16.3 \%(11.8-22.6 \%)$, while that of five shale samples from Well PS18-8 is $13.4 \%$ (6.7-20.9\%) (Luo et al. 2013), showing that the shale in Well PS18-1 has a higher porosity. As shown in Figs. 2 and 3, evaporites are well developed in $\mathrm{Es}_{3}{ }^{\mathrm{U}}$, and their sealing capacity is excellent and could prevent oil leakage. The strong overpressure developed in this stratum further illustrates this sealing capacity. The acoustic time differences and density logging data in the $\mathrm{Es}_{3}{ }^{\mathrm{U}}$ target interval (3250-3285 m) of Well PS18-1 have averages of $349 \mu \mathrm{s} / \mathrm{m}(252-434 \mu \mathrm{s} / \mathrm{m})$ and $2.44 \mathrm{~g} / \mathrm{cm}^{3}(2.32-$ $2.58 \mathrm{~g} / \mathrm{cm}^{3}$ ), whereas the respective averages in the $\mathrm{Es}_{3}{ }^{\mathrm{U}}$ target interval (3155-3195 m) of Well PS 18-8 are $277 \mu \mathrm{s} / \mathrm{m}$ $(240-300 \mu \mathrm{s} / \mathrm{m})$ and $2.54 \mathrm{~g} / \mathrm{cm}^{3}\left(2.25-2.65 \mathrm{~g} / \mathrm{cm}^{3}\right)$, showing that the shale at Well PS18-1 has a higher acoustic time difference but clearly a smaller density than the shale at Well PS18-8 (Fig. 12), which may be induced by the evaporites enrichment. However, as shown in Fig. 3, the development degree of the evaporites in depth interval of $3155 \mathrm{~m}-3195 \mathrm{~m}$ of the Well PS18-8 is significantly greater than that of depth interval of $3250 \mathrm{~m}-3285 \mathrm{~m}$ of the Well PS18-1, further indicating that the shale in Well PS18-1 has a higher porosity. In comparison, the $\mathrm{Es}_{3}{ }^{\mathrm{U}}$ shale oil play in this study has a significantly greater porosity compared to the shales in other lacustrine basins in China and typical shale oil plays in the USA (Table 3), which might be associated with the strong overpressure. Therefore, the reservoir conditions of the shale oil play in the DD are very good and are conducive to the shale oil enrichment. Similar to the oil enrichment mechanism in the fractures (see Section 4.2.1), the oil accumulated in the pores could be oil that either generated from in situ shale or migrated a short distance from adjacent shale, which is mainly movable oil. As for the shale reservoir, the connectivity between pores is very poor, but most of the oil that has accumulated in these pores cannot be recovered without anthropogenic fracturing (Jarvie 2012; Li et al. 2014). In this study, without anthropogenic fracturing, a shale oil yield of $430 \mathrm{~m}^{3} / \mathrm{d}$ was obtained at Well PS18-1, indicating that the produced oil is likely the movable oil from fractures rather than pores. Therefore, the fracture density might be a key factor controlling shale oil enrichment.

\subsection{Frackability}

To obtain commercial oil yield from low-porosity and -permeability shale oil plays, large-scale horizontal wells and anthropogenic fracturing techniques are required to improve the seepage capacity. Shale frackability depends mainly on the natural fracture development and mineral composition (Jarvie et al. 2007; Wang et al. 2015b).

Natural fractures in shale could reduce the tensile strength of the rock and enhance the fracturing effect. The more developed the natural fractures are, the more favorable conditions are for creating interconnected fractures when fracturing (Montgomery et al. 2005). The natural fractures in the $\mathrm{Es}_{3}{ }^{\mathrm{U}}$ shale are well developed, and the interaction between different types of fractures can form complex fracture systems, which are favorable for fracture networks formation by anthropogenic fracturing. Despite the extensive fracture 


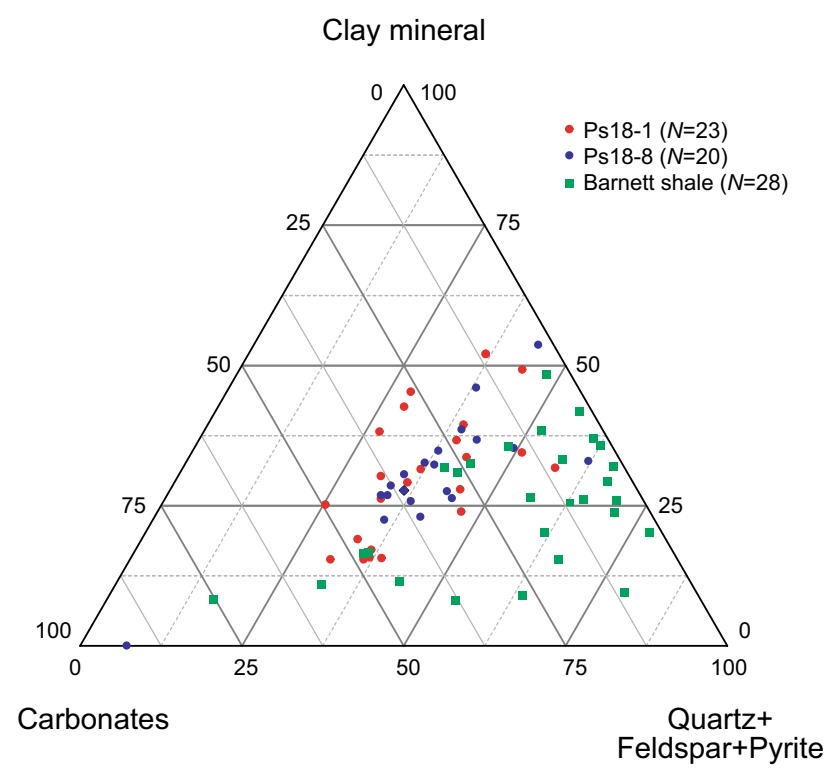

Fig. 13 Ternary diagram of clay minerals, carbonates, and quartz + feldspar + pyrite of $\mathrm{Es}_{3}{ }^{\mathrm{U}}$ shale in Liutun Sag, DD. Compared with the mineral composition of Barnett shales (Loucks and Ruppel 2007), the $\mathrm{Es}_{3}{ }^{\mathrm{U}}$ shale has higher enrichment of carbonates and clay minerals and a relative lack ofquartz, feldspar, and pyrite. $N$ indicates the number of samples

development in the $\mathrm{Es}_{3}{ }^{\mathrm{U}}$ shale, nearly $70 \%$ of them are filled by calcite and saline minerals, resulting in a decrease in permeability of the shale. However, these fractures are weak surfaces that are easily reopened after anthropogenic fracturing, which is very common in Barnett Shale play (Montgomery et al. 2005). Therefore, given the natural fracture density, the $\mathrm{Es}_{3}{ }^{\mathrm{U}}$ shale has an excellent frackability. Considering that the fracture density of the shale in Well PS18-1 is higher than Well PS18-8, we can infer that the shale in Well PS18-1 has a better frackability.

The XRD analysis shows that the $\mathrm{Es}_{3}{ }^{\mathrm{U}}$ shale is composed of detrital minerals (quartz and feldspar), clay minerals, carbonates, and saline minerals, with average contents of $32 \%(13-58 \%), 28 \%(8-52 \%), 28 \%(2-52 \%)$, and $9 \%$ (0-62\%), respectively. In comparison with shale oil plays in other lacustrine basins, the shale oil play in the DD has lower quartz and clay mineral contents, similar carbonate contents, but higher saline mineral contents. Unlike the shale oil plays in the USA, the $\mathrm{Es}_{3}{ }^{\mathrm{U}}$ shale has a mineral composition that varies significantly and is abundant in carbonates, clay, and saline minerals (Fig. 13; Tables 3, 4) (Montgomery and Morea 2001; Montgomery et al 2005; Jarvie et al. 2007; Loucks and Ruppel 2007; Jarvie 2008, 2012; Han et al. 2014). This is because the $\mathrm{Es}_{3}{ }^{\mathrm{U}}$ shale comprises a set of fine-grained sediments that developed in a small hypersaline lacustrine basin with a strong reducing environment, which provided large amounts of chemical deposits but received less terrestrial clastic material.
The higher the brittle mineral contents are, the better the fracturing effect is for the shale (Loucks and Ruppel 2007). Among the mineral components in the $\mathrm{Es}_{3}{ }^{\mathrm{U}}$ shale, the clay minerals have the highest content, which are prone to plastic deformation, leading to the blockage of seepage channels and subsequent difficulty in shale fracturing (Wilson et al. 2014; Zeinijahromi et al. 2016; Wei et al. 2019). The content of feldspar, which is unstable and easily dissolved, is also high, with an average of $14 \%$ (5-52\%). Quartz, calcite, and dolomite have average contents of $18 \%(4-28 \%), 15 \%(0-47 \%)$, and $12 \%(0-45 \%)$, respectively, and brittleness evaluation of the shales in the USA (Montgomery and Morea 2001; Loucks and Ruppel 2007) has suggested that these three minerals are favorable for induced fracturing. This study utilizes the brittleness index $(\mathrm{BI})=($ quartz + calcite + dolomite + pyrite $) /($ total minerals) to characterize the frackability (Wang and Gale 2009; Chen et al. 2011; Zou 2011; Qiu et al. 2016). The results show that the average $\mathrm{BI}$ of the $\mathrm{Es}_{3}{ }_{3}^{\mathrm{U}}$ shale is $0.47(0.07-0.72)$ (Table 4). In general, when BI is larger than 0.4, the shale has good frackability, such as the Barnett and Woodford shale (Sondergeld et al. 2010). Thus, the $\mathrm{Es}_{3}{ }^{\mathrm{U}}$ shale is suitable for anthropogenic fracturing. Specifically, the average BI values of the shale in Wells PS18-1 and PS18-8 are 0.42 (0.07-0.72) and $0.48(0.22-0.59)$, respectively, indicating that the shales in these two wells are similar in frackability.

In summary, given the mineral compositions, little difference exists in the frackability of the shales in Wells PS18-1 and PS18-8, which are both suitable for fracturing. However, due to the higher fracture density of the shale in Well PS18-1 compared to Well PS18-8, the former has greater potential for anthropogenic fracturing.

\subsection{Oil mobility}

Oil mobility is an important index in evaluating shale oil recovery, which is determined by oil properties, reservoir seepage capacity, and formation pressure.

For low-porosity and low-permeability shale oil plays, low-density and low-viscosity oil is more likely to be produced. This is probably the reason why shale oils produced presently are primarily light oils (Nelson 2009; Zhang et al. 2012; Zou et al. 2013; Nie et al. 2016). Generally, the higher the saturated hydrocarbons contents are and the lower the nonhydrocarbon and asphaltene contents are, the lower the oil density and viscosity are, and therefore the higher the oil mobility is (Kuhn et al. 2012; Li et al. 2014). The oil produced from Well PS18-1 in the DD has a high density of $0.935 \mathrm{~g} / \mathrm{cm}^{3}$, a high viscosity of $43 \times 10^{3} \mathrm{mPa} \cdot \mathrm{s}$, and very poor mobility because the $\mathrm{Es}_{3}{ }^{\mathrm{U}}$ shale has a shallow burial depth and low thermal maturity, resulting in a high contents of nonhydrocarbons $(23.06 \%)$ and asphaltenes (26.68\%), and a low contents of saturated hydrocarbons (36.79\%) and aromatic hydrocarbons (13.47\%). Therefore, in terms of the 


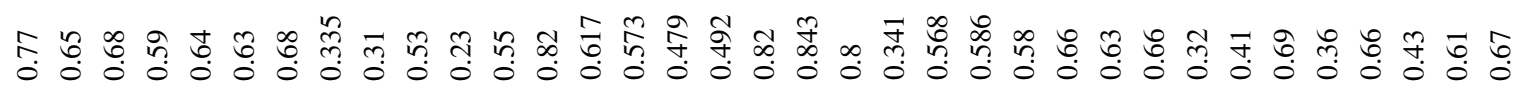

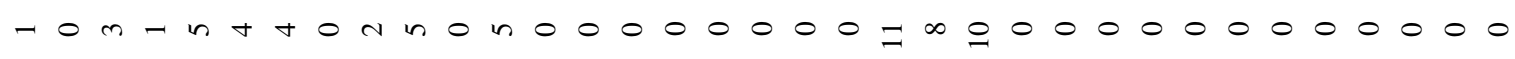

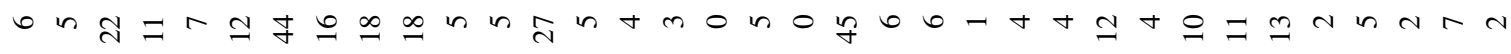

\section{1}

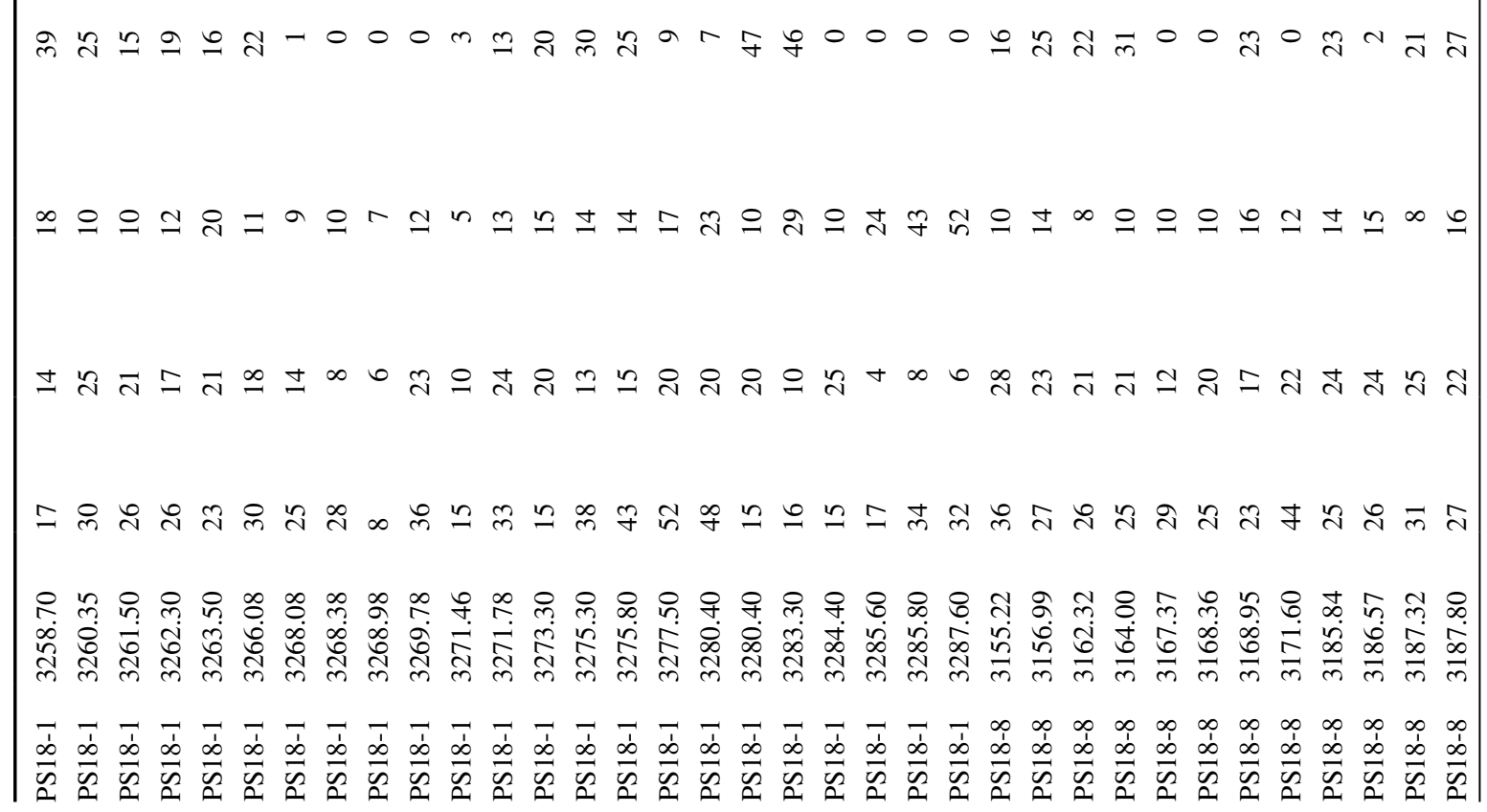




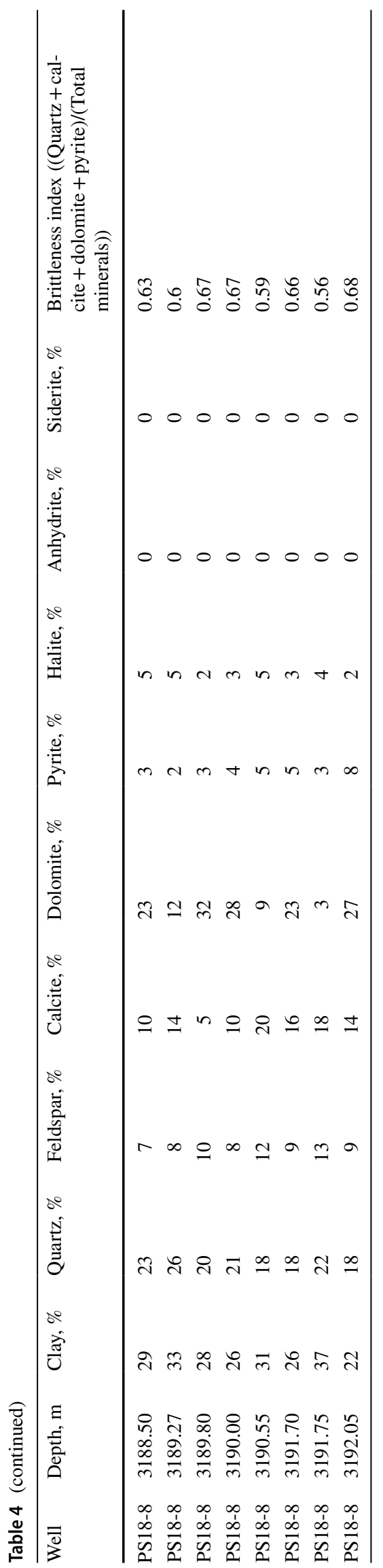

physical properties of the oil, the oil mobility of the $\mathrm{Es}_{3}{ }^{\mathrm{U}}$ shale oil play is poor.

The seepage capacity of a shale is mainly related to the fracture density. Previous studies proposed that fractures can increase the shale permeability by 4-5 orders of magnitude (Zhang et al. 2012). As described in Section 4.2.1, the fractures in the $\mathrm{Es}_{3}{ }^{\mathrm{U}}$ shale are extremely well developed and the shale should have a strong seepage capacity. Specifically, compared with the shale in Well PS18-8, Well PS18-1 has a significantly higher fracture density, indicating that the seepage capacity of the shale in Well PS18-1 should be considerably better than Well PS18-8.

Overpressure provides natural driving forces for shale oil production and can improve oil flow rates and shale fracturing efficiency significantly (Ronald et al. 2007). Overpressure is commonly developed in the shale oil plays in the USA (Jarvie 2012). As shown in Fig. 12, the variations in acoustic time differences and mud density logging data with respect to depth indicate that the overpressure conditions should be widely developed in the $\mathrm{Es}_{3}{ }^{\mathrm{U}}$ strata, which were also reported in other studies ( $\mathrm{Li}$ and Zhao 2012; Luo et al. 2016). However, except for the overpressure, the high acoustic time differences and low mud density can also be caused by evaporites. Generally, the logging data of the evaporites are characterized by high acoustic time differences and low mud density. Further analyses of the rock lithology assemblage show that, for the Well PS18-1, no evaporites developed in the depth interval of 3250-3285 m, while the evaporites are well developed in the depth interval of 3155-3195 $\mathrm{m}$ at Well PS18-8 (Fig. 3). Therefore, in terms of the evaporites, the acoustic time differences of the shale interval of the Well PS18-1 should be lower than Well PS18-8 and the density logging data of the shale interval of the Well PS18-1 should be greater than Well PS18-8. However, as shown in Fig. 12, the acoustic time difference of the Well PS18-1 $(349 \mu \mathrm{s} / \mathrm{m}(252-434 \mu \mathrm{s} / \mathrm{m}))$ is significantly greater than Well PS18-8 (277 $\mu \mathrm{s} / \mathrm{m}(240-300 \mu \mathrm{s} / \mathrm{m}))$, and the density logging data of the Well PS18-1 $\left(2.44 \mathrm{~g} / \mathrm{cm}^{3}(2.32-2.58 \mathrm{~g} /\right.$ $\left.\mathrm{cm}^{3}\right)$ ) are lower than Well PS18-8 $\left(2.54 \mathrm{~g} / \mathrm{cm}^{3}(2.25-2.65\right.$ $\left.\mathrm{g} / \mathrm{cm}^{3}\right)$ ), indicating that the variations in acoustic time differences and mud density logging data are associated with overpressure, not evaporites. The overpressure indicates that the $\mathrm{Es}_{3}{ }^{\mathrm{U}}$ shale oil plays have excellent shale oil recovery. In contrast, the variation degree of logging data in the $\mathrm{Es}_{3}{ }^{\mathrm{U}}$ strata of the Well PS18-1 is significantly greater than that of the Well PS18-8 (Fig. 12), indicating a greater overpressure, which was further validated by the measured MDT formation pressure (the pressure coefficient of Well PS18-1 is 2.2, while the pressure coefficient of Well PS18-8 is 1.4). The overpressure differences between the two wells are closely related to the differential development of evaporites: a. Difference in 
assemblage and thickness of the evaporites. As shown in Fig. 3, the distribution of the evaporites is uniform and the thickness is thick at Well PS18-1, while the evaporites of Well PS18-8 are thin and interbedded with shale, indicating that the evaporites developed in Well PS18-1 should possess a greater sealing capacity; b. Difference in evaporites location. As shown in Fig. 3, the evaporites of Well PS18-1 developed at the top $(<3250 \mathrm{~m})$ and the bottom ( $>3285 \mathrm{~m}$ ) of the interval of interest (3250-3285 m), forming the typical top and bottom seals for an overpressure compartment, which are very conducive to preserving the overpressure. In contrast, the evaporites of Well PS18-8 developed in the middle (3167-3178 $\mathrm{m}$ ) of the interval of interest (3155-3195 m). Besides, these evaporites are thin and interbedded with shale at well PS18-8, which are unfavorable for preserving formation pressure. The above two factors jointly caused the formation pressure difference between the two wells. Therefore, the shale oil of the Well PS18-1 should have higher natural driving forces and a higher shale oil yield. Further comparison shows that the study area has a significantly higher formation pressure compared to the shale oil plays in other lacustrine basins in China and the marine basins in the USA (Table 3). Therefore, the shale oil play in the DD should have excellent oil mobility.

In summary, despite the high density and high viscosity of the oil, the $\mathrm{Es}_{3}{ }^{\mathrm{U}}$ shale reservoir has a strong seepage capacity and overpressure, representing excellent conditions for shale oil mobility. Given the lower thermal maturity, high-density, high-viscosity oil, and high formation pressure, the study area is similar to the Santanghu Basin, where high shale oil production has been realized from the Lucaogou Formation (Table 3) (Nie et al. 2016). In comparison, due to the superior seepage capacity of the shale reservoir and the greater formation pressure, the oil mobility of the Well PS18-1 is superior to that of the Well PS18-8 well. Oil mobility is the most important condition determining the remarkable yield difference between these two wells.

\subsection{Implications for further shale oil exploration}

By investigating the basic conditions of the shales at Wells PS18-1 and PS18-8, the fracture density and overpressure condition are the key factors controlling shale oil enrichment in the DD. The extensively developed fractures can not only increase the reservoir volume of the shale, facilitating the shale oil accumulation, but also improve the seepage capacity of shale reservoirs significantly. Meanwhile, in the setting of extensively fractures, the overpressure furtherly promotes the natural driving forces for the shale oil in the $\mathrm{DD}$, increasing the shale oil mobility. This is contrary to the previous common perception, which indicated the developed fractures would promote the oil and gas loss in the shale system and then result in the decreasing oil and gas enrichment (Rodriguez and Paul 2010; Liu et al. 2013). This should be closely related to extensive evaporites developed in the Dongpu Depression, which significantly increase the preservation conditions. This phenomenon can also be seen in the adjacent Dongying Depression. The fracture density is determined by the distance to the faults in a basin, and the closer to the faults is, the greater density the fractures is. The formation pressure was determined by the assemblage and thickness of the evaporites. Furthermore, as indicated in Fig. 12c and d, high abnormal overpressures are very common in strata deeper than the $\mathrm{Es}_{3}{ }_{3}^{\mathrm{U}}$. Besides, the oil generated in deep shales with higher thermal maturity is more likely to have low density and low viscosity and better oil mobility. Therefore, the $\mathrm{Es}_{3}$ strata in deep depressions are also favorable for future shale oil exploration. Similar to the general tectonic and depositional settings of the DD, large amounts of saline lacustrine rift basins were developed across the world, in which faults and evaporites developed commonly. In future shale oil exploration, the regions and strata adjacent to the faults and with thick evaporites should be preferably selected as sweet spots. The results obtained in this study could be instrumental in future shale oil exploration not only in the DD but also in lacustrine basins across the world.

\section{Conclusions}

$\mathrm{The} \mathrm{Es}_{3}{ }^{\mathrm{U}}$ shale in the DD has a high content of organic matter dominated by oil-prone type I and type II kerogens within oil window, displaying a strong petroleum generation potential. Despite the petroleum generation potential of the shale at Well PS18-8 is relatively greater than that of the shale at Well PS18-1, the oil content of the latter well is slightly greater due to the slightly greater TOC. Various types of pores and fractures are extensively developed in the $\mathrm{Es}_{3} \mathrm{U}$ shale, with an average porosity of $14.9 \%$, which is favorable for shale oil enrichment. The porosity and fracture density of the shale at Well PS18-1 are both greater than those of the shale at Well PS18-8, suggesting that the former is more favorable for shale oil enrichment. The $\mathrm{Es}_{3}{ }^{\mathrm{U}}$ shale has a high brittle mineral content and extensive fractures, which are conducive to anthropogenic fracturing. The shale at Well PS18-1 has a better anthropogenic fracturing potential than that at Well PS18-8 due to higher fracture density. The $\mathrm{Es}_{3}{ }^{\mathrm{U}}$ shale oil play has strong seepage capacity and overpressure, both of which are favorable for shale oil mobility. The $\mathrm{Es}_{3}{ }^{\mathrm{U}}$ shale oil play at Well PS18-1 has a better seepage capacity and higher overpressure than that at Well PS18-8, indicating that the shale at Well PS18-1 has a better oil mobility.

The key factors controlling shale oil enrichment of the $\mathrm{Es}_{3}{ }^{\mathrm{U}}$ shale oil play in the DD are the fracture density and 
overpressure, which were determined by the development of the faults and the assemblage and thickness of the evaporites, respectively. Therefore, in future shale oil exploration, the regions and strata adjacent to the faults and with thick evaporites should be preferably selected as sweet spots.

Acknowledgements This study was financially supported by the China Postdoctoral Science Foundation (2019M660054), Science Foundation of China University of Petroleum (Beijing) (2462019BJRC005), Strategic Cooperation Technology Projects of CNPC and CUPB (ZLZX202001-05), Natural Science Foundation of China (41872148, 41872128), NSFC Basic Research Program on Deep Petroleum Resource Accumulation and Key Engineering Technologies (U19B6003-02), and the Science Projects of the Sinopec Zhongyuan Oilfield Company (P15022).

Open Access This article is licensed under a Creative Commons Attribution 4.0 International License, which permits use, sharing, adaptation, distribution and reproduction in any medium or format, as long as you give appropriate credit to the original author(s) and the source, provide a link to the Creative Commons licence, and indicate if changes were made. The images or other third party material in this article are included in the article's Creative Commons licence, unless indicated otherwise in a credit line to the material. If material is not included in the article's Creative Commons licence and your intended use is not permitted by statutory regulation or exceeds the permitted use, you will need to obtain permission directly from the copyright holder. To view a copy of this licence, visit http://creativecommons.org/licenses/by/4.0/.

\section{References}

Bai J, Xu XY, Chen S. Analysis of controlling factors of shale oil enrichment and recoverable capacity in continental shale, a case study from qingshankou formation. Geol Rev. 2017;63(S1):117-8. https://doi.org/10.16509/j.georeview.2017.s1.056 (in Chinese).

Burgess JD. Microscopic examination of kerogens (dispersed organic matter) in petroleum exploration. Geol Soc Am Bull. 1974;153:19-30. https://doi.org/10.1130/spe153-p19.

Cao QY. Identification of micro-components and types of kerogen under transmitted light. Pet Explor Dev. 1985;5:14-23 (in Chinese).

Carbonel P. Ostracods and the transition between fresh and saline waters. Ostracoda in the Earth Sciences.1988; 157-73.

Chen FL, Zhu H, Li XT, et al. Partition of sequence strata and discussion about salt-rock resource in Shahejie Formation of Eogene, Dongpu Depression. Acta Sedimentologica Sinica. 2000; 03: 384-388+394. https://doi.org/10.14027/j.cnki.cjxb.2000.03.010. (in Chinese).

Chen SB, Zhu YM, Wang HY, et al. Shale gas reservoir characterization: a typical case in the southern Sichuan Basin of China. Energy. 2011;36(11):6609-16. https://doi.org/10.1016/j.energy. 2011.09.001.

Chen SP, Xu SS, Wang DR, et al. Effect of block rotation on fault sealing: an example in Dongpu sag, Bohai Bay Basin. China Mar Pet Geol. 2013;39(1):39-47. https://doi.org/10.1016/j.marpetgeo. 2012.10.002.

Chen ZH, Wang TG, Liu Q, et al. Quantitative evaluation of potential organic-matter porosity and hydrocarbon generation and expulsion from mudstone in continental lake basins: a case study of Dongying sag, eastern China. Mar Pet Geol. 2015;66:906-24. https:// doi.org/10.1016/j.marpetgeo.2015.07.027.
Curtis JB. Fractured shale-gas systems. AAPG Bull. 2002;86:9211938. https://doi.org/10.1306/61eeddbe-173e-11d7-8645000102 c1865d.

Deng ED, Zhang JC, Zhang P, et al. Geological condition and favorable areas of shale oil in upper-submember of Es3 Formation in Northern Dongpu Sag. J Shandong Univ Sci Technol. 2015;34(3):28 37. https://doi.org/10.16452/j.cnki.sdkjzk.20150619.002 (in Chinese).

Duan HM, Gao P, Wang XW, et al. The secondary hydrocarbon generation of the Shahejie source rocks in the Dongpu Depression. J Oil Gas Technol. 2008;1:206-9 (in Chinese).

Eia US. Technically recoverable shale oil and shale gas resources: an assessment of 137 shale formations in 41 countries outside the United States. Washington DC: US Department of Energy/EIA; 2008.

Enderlin M, Alsleben H, Beyer J. Predicting fracability in shale reservoirs. Houston, Texas, USA: AAPG Annual Convention and Exhibition; 2011.

Espitalié J, Laporte LJ, Madec M, et al. Méthode rapide de caractérisation des roches mètres, de leur potentiel pétrolier et de leur degré d'évolution. Revue de l'Institut français du Pétrole. 1977;32(1):23-42. https://doi.org/10.2516/ogst:1977002.

Ferrill DA, Morris AP, Hennings PH, et al. Faulting and fracturing in shale and self-source reservoirs. Introduction. AAPG Bull. 2014;98(11):2161-4. https://doi.org/10.1306/intro073014.

Han YJ, Horsfield B, Wirth R, et al. Oil retention and porosity evolution in organic rich shales. AAPG Bull. 2014;101(6):807-27. https://doi.org/10.1306/09221616069.

Hu T, Pang XQ, Jiang S, Wang QF, et al. Oil content evaluation of lacustrine organic-rich shale with strong heterogeneity: a case study of the Middle Permian Lucaogou Formation in Jimusaer Sag, Junggar Basin. NW China Fuel. 2018a;221:196-205. https:// doi.org/10.1016/j.fuel.2018.02.082.

Hu T, Pang XQ, Jiang S, et al. Impact of paleosalinity, dilution, redox, and paleoproductivity on organic matter enrichment in a saline lacustrine rift basin: a case study of paleogene organic-rich shale in dongpu depression, Bohai Bay basin. Eastern China Energy Fuels. 2018b;32(4):5045-61. https://doi.org/10.1021/acs.energ yfuels. 8 b00643.

Huang DF, Li JC, Zhou ZH, et al. Evolution and hydrocarbon generation mechanisms of terrestrial organic matter. Beijing: Petroleum Industry Press; 1984. (in Chinese).

İnan S, Goodarzi F, Schmidt A, et al. The Silurian Qusaiba hot shales of saudi arabia: an integrated assessment of thermal maturity. Int J Coal Geol. 2016;159:07-119. https://doi.org/10.1016/j.coal. 2016.04.004.

Jarvie DM. Unconventional shale resource plays: shale-gas and shaleoil opportunities: Texas Chtistian Unversity, Wordwide Geochemistry. 2008.

Jarvie DM. Shale resource systems for oil and gas: part 2: shale-oil resource systems. Shale reservoirs-giant resources for the $21 \mathrm{st}$ century. AAPG Memoir. 2012;97:89-119.

Jarvie DM, Hill RJ, Ruble TE, et al. Unconventional shale-gas systems: the Mississippian Barnett Shale of north-central Texas as one model for thermogenic shale-gas assessment. AAPG Bull. 2007;91(4):475-99. https://doi.org/10.1306/12190606068.

Jiang FJ, Pang XQ, Bai J, et al. Comprehensive assessment of source rocks in the Bohai Sea area, eastern China. AAPG Bull. 2016;100(6):969-1002. https://doi.org/10.1306/02101613092.

Jiang S, Feng YL, Chen L. Multiple-stacked Hybrid Plays of lacustrine source rock intervals: case studies from lacustrine basins in China. Pet Sci. 2017;14(3):459-83. https://doi.org/10.1007/ s12182-017-0179-9.

Jiao YJ, Zhang H, Xue DC. Application and comparison of fresh fracture secondary electron SEM and ion-milled backscatter SEM for shale sample preparation. J Chin Electron Microsc Soc. 
2016;35(6):544-9. https://doi.org/10.3969/j.issn.1000-6281.2016. 06.013 (in Chinese).

Katz BJ. Factors controlling the development of lacustrine petroleum source rocks-An Update. In Paleogeography, Paleoclimate, and Source Rocks. Huc AY, Ed. AAPG Studies in Geology. AAPG, Tulsa, Oklahoma. 1995.

Katz BJ, Arango I. Organic porosity: a geochemist's view of the current state of understanding. Org Geochem. 2018;123:1-16. https://doi. org/10.1016/j.orggeochem.2018.05.015.

Katz BJ, Kahle GM. Basin evaluation: a supply-side approach to resource assessment. Indones Pet Assoc. 1988;1:135-68. https:// doi.org/10.29118/ipa.2260.135.168.

Katz BJ, Lin F. Lacustrine basin unconventional resource plays. Key Diff Mar Pet Geol. 2014;56:255-65. https://doi.org/10.1016/j. marpetgeo.2014.02.013.

Kuhn PP, Primio RD, Hill R, et al. Three-dimensional modeling study of the low-permeability petroleum system of the Bakken Formation. AAPG Bull. 2012;96(10):1867-97. https://doi.org/10.1306/ 03261211063.Leng.

Leng JG, Liu XF, Pang XQ. Overpressured fractured mudstone reservoir in salt-mud interbed: a case from Wenliu structure in Dongpu Sag. Petroleum Exploration and Development. 2006;33(6):692-6 (in Chinese).

Li XQ, Zhao YC. Overpressure genesis in the Liutun salt-lake sag, Dongpu Depression, Bohai Bay Basin. Oil Gas Geol. 2012;33(5):686-94 (in Chinese).

Li JJ, Shi YL, Zhang XW, et al. Control factors of enrichment and producibility of shale oil: a case study of Biyang Depression. Earth Sci J Chin Univ Geosci. 2014;39(7):848-57 (in Chinese).

Li TW, Jiang ZX, Li Z, et al. Continental shale pore structure characteristics and their controlling factors: a case study from the lower third member of the shahejie formation, zhanhua sag, eastern china. J Nat Gas Sci Eng. 2017;45:670-92. https://doi.org/10. 1016/j.jngse.2017.06.005.

Liu B, Chi YA, Huang ZL, et al. Migration mechanism of the Permian hydrocarbon and shale oil accumulation in Malang Sag, the Santanghu Basin. Oil Gas Geol. 2013;34(6):725-30. https://doi.org/ 10.11743/ogg20130602 (in Chinese).

Liu CL, Wang ZL, Guo ZQ, et al. Enrichment and distribution of shale oil in the Cretaceous Qingshankou Formation, Songliao Basin. Northeast China Mar Pet Geol. 2017;86:751-70. https://doi.org/ 10.1016/j.marpetgeo.2017.06.034.

Liu B, Shi JX, Fu XF, et al. Petrological characteristics and shale oil enrichment of lacustrine fine-grained sedimentary system: a case study of organic-rich shale in first member of Cretaceous Qingshankou Formation in Gulong Sag, Songliao Basin. NE China Pet Explor Dev. 2018;45(5):884-94. https://doi.org/10.1016/s18763804(18)30091-0.

Loucks RG, Ruppel SC. Mississippian Barnett Shale: Lithofacies and depositional setting of a deep-water shale-gas succession in the Fort Worth Basin. Texas AAPG Bull. 2007;91(4):579-601. https://doi.org/10.1306/11020606059.

Loucks RG, Reed RM, Ruppel SC, et al. Morphology, genesis, and distribution of nanometer-scale pores in siliceous mudstones of the Mississippian Barnett Shale. J Sediment Res. 2009;79(12):84861. https://doi.org/10.2110/jsr.2009.092.

Loucks RG, Reed RM, Ruppel SC. Spectrum of pore types and networks in mudrocks and a descriptive classification for matrixrelated mudrock pores. AAPG Bull. 2012;96(6):1071-98. https:// doi.org/10.1306/08171111061.

Luo Y, Zhao YC, Lv XH. Characterization of the upper Es3 inter-salt shale reservoir in Liutun sag. Dongpu Depression Acta Pet Sin. 2013;34(2):293-300. https://doi.org/10.7623/syxb201302011. (inChinese).
Luo Y, Zhao YC, Chen HH, et al. Fracture characteristics under the coupling effect of tectonic stress and fluid pressure: a case study of the fractured shale oil reservoir in Liutun subsag, Dongpu Sag, Bohai Bay Basin. Eastern China Pet Explor Dev. 2015;42(2):196205. https://doi.org/10.1016/s1876-3804(15)30006-9.

Luo Y, Liu HP, Zhao YC, et al. Reevaluation of the origin of overpressure in the inter-salt shale-oil reservoir in Liutun Sag, Dongpu Depression, China. J Petrol Sci Eng. 2016;146:1092-100. https:// doi.org/10.1016/j.petrol.2016.08.011.

Luo QY, Qu Y, Chen Q, et al. The organic geochemistry and petrology of mudrocks from the Upper Carboniferous Batamayineishan Formation, Wulungu area, Junggar Basin, China: Implications for the petroleum exploration. Energy Fuels. 2017;31(10):10628-38. https://doi.org/10.1021/acs.energyfuels.7b01754.

Mello MR, Mohriak WU, Koutsoukos AM, et al. Brazilian and west African oils: Generation, migration, accumulation and correlation. Proceedings 13th World Petroleum Congress. 1991;2:153-64.

Montgomery SL, Morea MF. Antelope shale (Monterey Formation), Bbuena Vista Hills field: Advanced reservoir characterization to evaluate $\mathrm{CO} 2$ injection for enhanced oil recovery. AAPG Bull. 2001;85(4):561-85. https://doi.org/10.1306/8626c947-173b$11 \mathrm{~d} 7-8645000102 \mathrm{c} 1865 \mathrm{~d}$.

Montgomery SL, Jarvie DM, Bowker KA. Mississippian Barnett Shale, Fort Worth basin, north-central Texas: gas-shale play with multitrillion cubic foot potential. AAPG Bull. 2005;89(2):155-75. https://doi.org/10.1306/09170404042.

Mu XS, Yuan XR, Jia YF. The formation conditions and the distribution characteristics of the oil pools in the fractures of the shales in Dongpu depression. Fault-Block Oil Gas Field. 2003;10(1):12-4 (in Chinese).

Nelson PH. Pore-throat sizes in sandstones, tight sandstone and shales. AAPG Bull. 2009;93(3):329-40. https://doi.org/10.1306/10240 808059 .

Nie HK, Zhang PX, Bian RK, et al. Oil accumulation characteristics of China continental shale. Earth Sci Front. 2016;23(2):55-62. https://doi.org/10.13745/j.esf.2016.02.007.(inChinese).

Peters KE, Cassa MR. Applied source rock geochemistry. In: Magoon LB, Dow WG, editors. The petroleum system - from source to trap Vol 60. AAPG Memoir; 1994. p. 93-120.

Qiu XW, Liu CY, Mao GZ, et al. Major, trace and platinum-group element geochemistry of the Upper Triassic nonmarine hot shales in the Ordos basin. Central China Appl Geochem. 2015;53:42-52. https://doi.org/10.1016/j.apgeochem.2014.11.028.

Qiu Z, Tao HF, Zou CN, et al. Lithofacies and organic geochemistry of the Middle Permian Lucaogou Formation in the Jimusar Sag of the Junggar Basin, NW China. J Petrol Sci Eng. 2016;140:97-107. https://doi.org/10.1016/j.petrol.2016.01.014.

Rahman M, Kinghorn RRF. A practical classification of kerogens related to hydrocarbon generation. J Pet Geol. 1995;18(1):91-102. https://doi.org/10.1306/bf9ab74f-0eb6-11d7-8643000102c1865d.

Reed RM, Loucks R, Milliken KL. Heterogeneity of shape and microscale spatial distribution in organic-matter-hosted pores of gas shales. AAPG-ACE, April 22-25, Long Beach, CA. 2012.

Rodriguez ND, Paul PR. Geochemical characterization of gases from the Mississippian Barnett Shale, Fort Worth Basin. Texas AAPG Bull. 2010;94(11):1641-56. https://doi.org/10.1306/04061 009119.

Ronald JH, Daniel MJ, Zumberge J, et al. Oil and gas geochemistry and petroleum systems of the Fort Worth Basin. AAPG Bull. 2007;91(4):445-73. https://doi.org/10.1306/11030606014.

Saikia MM, Dutta TK. Depositional environments of source beds of high-wax oils in Assam basin. India AAPG Bull. 1980;64(3):42730. https://doi.org/10.1306/2f91899b-16ce-11d7-8645000102 c1865d. 
Sondergeld CH, Newsham KE, Rice MC, et al. Petrophysical Considerations in Evaluating and Producing Shale Gas Resources. SPE, February 2010, Pittsburgh, USA.

Tao S, Wang YB, Tang DZ, et al. Organic petrology of Fukang Permian Lucaogou Formation oil shales at the northern foot of Bogda Mountain, Junggar Basin. China Int J Coal Geol. 2012;99:27-34. https://doi.org/10.1016/j.coal.2012.05.001.

Tissot BP, Welte DH. Petroleum formation and occurrence. New York: Springer; 1984.

Tyson RV. Sedimentary organic matter: organic facies and palynofacies. London: Chapman \& Hall; 1995.

Ufer K, Stanjek H, Roth G, et al. Quantitative phase analysis of bentonites by the Rietveld method. Clays Clay Miner. 2008;56(2):27282. https://doi.org/10.1346/ccmn.2008.0560210.

Wang FP, Gale JFW. Screening criteria for shale-gas systems. Gulf Coast Assoc Geol Soc Trans. 2009;59:779-93.

Wang M, Shi L, Wang WG, et al. Comparative study on geochemical characteristics of shale oil between China and U.S.A. Lithologic Reserv. 2014;26(3):67-73.

Wang ZH, Su H, Zeng T, Ma A. Analyzing the conditions of forming deep-seated oil/gas reservoir around Liutun Sag in Dongpu Depression. Nat Gas Ind. 2014;24:15-7 (in Chinese).

Wang M, Sherwood N, Li ZS, et al. Shale oil occurring between salt intervals in the Dongpu Depression, Bohai Bay Basin. China Int J Coal Geol. 2015a;152:100-12. https://doi.org/10.1016/j.coal. 2015.07.004

Wang M, Wilkins RWT, Song GQ, et al. Geochemical and geological characteristics of the Es3L lacustrine shale in the Bonan sag, Bohai Bay Basin. China Int J Coal Geol. 2015b;138:16-29. https://doi.org/10.1016/j.coal.2014.12.007.

Wang PF, Jiang ZX, Ji WM, et al. Heterogeneity of intergranular, intraparticle and organic pores in Longmaxi shale in Sichuan Basin, South China: evidence from SEM digital images and fractal and multifractal geometries. Mar Pet Geol. 2016a;72:122-38. https:// doi.org/10.1016/j.marpetgeo.2016.01.020.

Wang XZ, Zhang LX, Li ZT, et al. Pore type classification scheme for continental Yanchang shale in Ordos Basin and its geological significance. Oil Gas Geol. 2016b;37(1):1-7. https://doi.org/10. 11743/ogg20160101.(inChinese).

Wang Y, Liu HM, Song GQ, et al. Enrichment controls and models of shale oil in the Jiyang Depression, Bohai Bay Basin. Geol J China Univ. 2017;23(2):268-76 (in Chinese).

Wang M, Guo ZQ, Jiao CX, et al. Exploration progress and geochemical features of lacustrine shale oils in China. J Pet Sci Eng. 2019;178:975-86. https://doi.org/10.1016/j.petrol.2019.04.029.
Wang WY, Pang XQ, Chen ZX, et al. Improved methods for determining effective sandstone reservoirs and evaluating hydrocarbon enrichment in petroliferous basins. Appl Energy. 2020;261:114457.

Wei YC, Li C, Cao DY, et al. The effects of particle size and inorganic mineral content on fines migration in fracturing proppant during coalbed methane production. J Petrol Sci Eng. 2019;182:106355. https://doi.org/10.1016/j.petrol.2019.106355.

Wilson MJ, Wilson L, Patey I. The influence of individual clay minerals on formation damage of reservoir sandstones: a critical review with some new insights. Clay Miner. 2014;47(2):147-64. https:// doi.org/10.1180/claymin.2014.049.2.02.

Wu GX, Wang ZP, Sun JB, et al. Problem discussion on evaluation of continental source rocks. Fault-Block Oil Gas Field. 2013;10(3):28-31. https://doi.org/10.3969/j.issn.1005-8907.2003. 03.009 (in Chinese).

Zeinijahromi A, Farajzadeh R, Bruining J, et al. Effect of fines migration on oil-water relative permeability during two-phase flow in porous media. Fuel. 2016;176:222-36. https://doi.org/10.1016/j. fuel.2016.02.066.

Zhang JC, Lin LM, Li YX. Classification and evaluation of shale oil. Earth Sci Front. 2012;19(5):322-31 (in Chinese).

Zhang J, Lu K, Jiang FH, et al. Enrichment condition of shale oil and gas in Dongpu Depression. Fault-Block Oil Gas Field. 2015;22(2):184-8 (in Chinese).

Zhao XZ, Zhou LH, Pu XG, et al. Exploration breakthroughs and geological characteristics of continental shale oil: a case study of the Kongdian Formation in the Cangdong Sag. China Mar Pet Geol. 2019;102:544-56. https://doi.org/10.1016/j.marpetgeo.2018.12. 020.

Zheng LJ, Wang HT, Meng JH, et al. The oil and gas industry standard of the People's Republic of China: analysis method for fractions of rock extract and crude oil (SY/T 5119-2008). Beijing: Petroleum Industry Press; 2008.

Zou CN. Unconventional petroleum geology (second edition). Beijing: Geological Publishing House; 2011.

Zou CN, Yang Z, Cui JW, et al. Formation mechanism, geological characteristics and development strategy of nonmarine shale oil in China. Pet Explor Dev. 2013;40(1):15-27. https://doi.org/10. 1016/s1876-3804(13)60002-6. 